\title{
SYNOPSIS OF THE LUCINACEA AND OF THE AMERICAN SPECIES.
}

\author{
By William Healey Dall, \\ Honorary Curator, Division of Mollusks.
}

The present paper is a continuation of the series of synopses of various groups of our marine bivalve shells, of which the Leptonacea, Solenidæ, Tellinidæ, and Cardiidæ have already appeared in these Proceedings, ${ }^{1}$ and other groups have been similarly treated elsewhere.

The Lucinacea is a fairly homogeneous group of families, apparently of very ancient lineage if the Silurian type referred to it is really akin. Mesozoic forms certainly occur, and, in the Tertiary, they are more numerous, more varied, and of greater size than in the recent fauna.

These papers make no attempt to review subordinate groups older than the Tertiary which are not represented in the Tertiary or recent faunas. The older groups require more time and material than is at the writer's disposal to treat them with thoroughness. On the other hand, most of the Tertiary genera are represented in the recent fauna, and some light on their affinities in doubtful cases can be gained from existing types.

The systematic arrangement of the Lucinacea, especially that of the typical family, is exceptionally confused, as it is more than half a century since the group, as such, has been revised even among the recent species, and makers of manuals seem to have accepted current statements with more than usual good nature. Many of the most common species go by names to which a very superficial examination would show they have no sufficient claim, and the manner in which unlike things have been lumped together is quite surprising.

\footnotetext{
${ }^{1}$ Synopsis of the Recent and Tertiary Leptonacea of North America and the West Indies. Proc. U. S. Nat. Mus. XXI, pp. 873-897, with plates LXXXviI, LXXXviII (No. 1177), June, 1899.

Synopsis of the Solenidæ of North America and the Antilles. Proc. U. S. Nat. Mus. XXII, pp 107-112 (No. 1185), October, 1899.

Synopsis of the Family Tellinidæ and of the North American species. Proc. U. S. Nat. Mus. XXIII, pp. 285-326, with plates II-IV (No. 1210), November, 1900.

Synopsis of the Family Cardiidæ and of the North American species. Proc. U. S. Nat. Mus. XXIII, pp. 381-392 (No. 1214), December, 1900.
} 
Most of the older names have been treated with indifference, and the same group has several times received a succession of names from authors who did not investigate the history or literature relating to it.

While it would be too much to expect that the present revision is absolutely free from error, it is believed that it takes a considerable step in advance over anything now published, and will at least direct attention to a very interesting group of Pelecypods.

The families included in the present revision are as follows:

\section{THYASIRIDA.}

Both coasts; 35 species in all. East coast, 28; west coast, 11.

\section{DIPLODONTID A.}

Both coasts; 20 species. East coast, 13; west coast, 9.

LUCINIDA.

Both coasts; 63 species.

\section{CORBID E.}

\section{Exotic? (Eastern Tertiaries.)}

\section{CYRENELLID A.}

East coast; 2 species.

All of these except the penultimate are represented in our recent fauna, and all in our Tertiary fauna. There are in all 120 species, of which 81 belong to the Atlantic, 45 to the Pacific, and only 5 (or possibly 6) are common to the two sides of the continent. The relative richness of the Atlantic coast is very marked, but of the Pacific species a large proportion, though not actually identical, are at least closely representative of Atlantic species, and doubtless are derived from a not remote common ancestor. As regards the Tertiary species, it may be said that, while nearly every recent group or species has its fossil analogue, we find as we recede in time, especially in the Eocene, a tendency for the subdivisions to coalesce or at least to lose their distinctive features and exhibit a mutability of character which, from the law of evolution, is exactly what we ought to expect. Contrary to my own anticipations, the superficial and ornamental characters are those which appear to be most strongly conserved from one horizon to another, through a series of geological epochs. Such features frequently come down from the Cretaceous or Lower Eocene with practically no change.

After satisfying myself that there was no mistake in this generalization, I concluded that this might be accounted for on the hypothesis that these characters, mostly due to trifling mutations of the armature of the mantle edge, are so little connected with essentials in the lives of these animals that, having been once acquired, natural selection has little or no influence upon them, and therefore rarely sets up any tendency to change. 


\section{BIBLIOGRAPHY.}

1758. Linnæus, Systema Naturæ, tenth edition.

1766. Linnæus, Systema Naturæ, twelfth edition.

1776. Forskal (in) Niebuhr, Voyage en Arabie, appendix.

1777. ScopoLI, Introd. ad Historia Naturalis.

1777. Pennant, British Zoology, IV.

1782. Spengler (in) Chemnitz, Conchylien Cabinet, VI.

1784. Chemnitz, Conchylien Cabinet, VII.

1787. Meuschen, Museum Geversianum.

1791. Poli, Testacea Utriusque Siciliæ, I.

1792. Guelin, Systema Naturæ, VI.

1797. Bruguière, Encyclopédie Méthodique: Vers, atlas.

1798. Poli, Testacea Utriusque Siciliæ, III.

1798. Bolten, Museum Boltenianum.

1798. Spengler, Skrifter Naturhistoriske Selskapet, IV.

1799. Lamarck, Prodrome d'un Nouveau Classification des Coquilles.

1801. Donovan, Natural History of British Shells, IV.

1801. Lamarck, Systéme des Animaux sans Vertébres.

1802. Daudin (in) Bosc, Histoire Naturelle des Coquilles, III.

1803. Montagu, Testacea Britannica.

1805. Rorssy, Sonnini's Buffon, Mollusques, VI.

1806. Lamarck, Annales du Muséum d'hist. Nat., VIII.

1807. Link, Beschreibung der Rostock sammlung.

1808. Montagu, Testacea Britannica, supplement.

1811. Megerle von Muhlfeld, Magasin der Gesellschaft Naturforschender Freunde zu Berlin.

1815. Wood, General Conchology.

1817. Dillwyn, Descriptive Catalogue of Recent Shells, I.

1817. Cuvier, Règne Animale, II.

1817. Schumacher, Essai d'un nouveau systéme des habitations des vers testacés.

1818. Lamarck, Histoire des Animaux sans Vertébres, V.

1820. Schweigger, Handbuch der Naturgeschichte.

1822. Turton, Dithyra Britannica or bivalve shells of the British Islands.

1822. SAY, Journal of the Academy of Natural Sciences, Philadelphia, II.

1823. Defrance, Dictionnnaire des, Sciences Naturelles.

1824. SAY, Journal of the Academy of Natural Sciences, Philadelphia, III.

1825. Gray, Thomson's Annals of Philosophy, XXV.

1825. Blainville, Manuel de Malacologie, I.

1825. Basterot, Mémoires de la Société d'histoire naturelle de Paris, II.

1826. Payraudeau, Catalogue des Mollusques de l'isle de Corse.

1827. Brown, Illustrations of the Recent Conchology of Great Britain.

1830. Menke, Synopsis Molluscorum in Museo Menkeano, second edition.

1830. Costa, Catalogo sist. e rag. de'Testacei delle due Sicilie.

1830. Deshayes, Encyclopédie Méthodique, Vers. II.

1831. Brons, Italiens Tertiär-Gebilde.

1833. Conrad, American Journal of Science, XXIII, No. 2.

1835. Deshayes, Bulletin, Société Géologique de France, VI.

1835. Joannis, Magasin de Zoologie, Guérin Méneville.

1836. Philippi, Enum. Moll. Siciliæ, I.

1836. Rogers, Transactions of the American Philosophical Society, 2d series, V.

1836. Deshayes, Expédition scientifique á la Morée.

1837. Conrad, Journal, Academy of Natural Sciences, Philadelphia, VII.

1837. Sowerby, Geological Transactions, $2 \mathrm{~d}$ series, IV. 
1838. WAGNer, Journal, Academy of Natural Sciences, Philadelphia, VIII.

1838. Conrad, Fossils of the Medial Tertiary of the United States, No. 1.

1839. D'Orbigny, Mollusques (etc.) recueilles aux iles Canaries par Barker-Webb et Berthelot.

1839. Jeffreys, Malacological and Conchological Magazine, I.

1840. Searles-Wood, Annals and Magazine of Natural History, VI.

1840. ConRad, Transactions American Association of Naturalists and Geologists, I.

1841. Goldfuss, Petrefacta Germaniæ, II.

1841. Gould, Invertebrata of Massachusetts.

1841. Conrad, American Journal of Science, XLI, October.

1842. Philippi, Wiegmann's Archiv für Naturgeschichte.

1842. D'Orbigny, Voyage dans l'Amérique Méridionale, Paléontologie.

1843. Deshayes, Magasin de Zoologie, Guérin-Méneville.

1843. De KAy, Natural History of New York, Part I, Zoology, Mollusca.

1844. Forbes, Report of the British Association for the Advancement of Science for 1843.

1844. Philıppi, Enum. Moll. Siciliæ, II.

1844. Hinds, Zoology of the Voyage of the Sulphur; Mollusca.

1845. Philıppi, Zeitschrift für Malakozoologie, II.

1845. H. C. Lea, Transactions, American Philosophical Society, 2d series, IX.

1845. C. B. Adams, Proceedings, Boston Society of Natural History, II.

1845. D'Orbigny, Mollusea Cubana, I; in Sagra, Histoire de l'isle de Cuba.

1846. PhilıpPI, Zeitschrift für Malakozoologie, III.

1846. D'Orbigny, Voyage dans l'Amérique Méridionale, Mollusques.

1847. Gray, Proceedings of the Zoological Society of London.

1847. Jefrreys, Annals and Magazine of Natural History, XX.

1847. Philıppi, Zeitschrift für Malakozoologie, IV.

1848. Dunker, Zeitschrift für Malakozoologie, V.

1848. Conrad, Journal, Academy of Natural Sciences, Philadelphia, 2d series, I.

1849. Conrad, U. S. Exploring Expedition, Report on the Geology, Appendix.

1850. MitrRé, Journal de Conchyliogie, I.

1850. Philippi, Abbildungen und Beschreibungen neue oder wenig gekannter conchylien, III, heft VII.

1850. Reeve, Conchologia Iconica, VII, Monograph of Lucina.

1850. PHILIPPI, Zeitschrift für Malakozoologie, VII.

1850. Gould, Report United States Exploring Expedition, Mollusca.

1850. Gould, Proceedings of the Boston Society of Natural History, III.

1851. Recluz, Journal de Conchyliologie, I.

1851. D'Orbigny, Prodrome de Paléontologie, II.

1851. Strmpson, Shells of New England.

1851. Gray, List of British Animals, British Museum.

1851. Morelet, Testacea Novissima insulæ Cubanæ et Am. centralis, II.

1852. D’Orbigny, Prodrome de Paléontologie, III.

1852. Gould, Boston Journal of Natural History, VI, Art. XXIV.

1852. C. B. Adams, Contributions to Conchology.

1852. LeAch, Mollusca of Great Britain, edited by Gray.

1852. Recluz, Journal de Conchyliologie, III.

1853. Searles Wood, Crag Mollusca, II. Bivalvia.

1853. Conrad, Proceedings Academy of Natural Sciences of Philadelphia, 1st series, VI.

1853. Mörch, Yoldi Catalogue, Part II.

1854. Huppé (in) Gay, Historia de Chile, VIII. Moluscos.

1855. Carpenter, Proceedings of the Zoological Society of London.

1856. Carpenter, Proceedings of the Zoological Society of London. 
1856. Tuomey and Holmes, Pleiocene Fossils of South Carolina.

1857. Carpenter, Catalogue of the Mazatlan shells in the British Museum.

1857. Мӧвсн, Rink's Greenland, appendix.

1857. H. and A. Adams, Genera of Recent Mollusca, II.

1857. Deshayes, Journal de Conchyliologie, VI.

1858. Jefrereys, Annals and Magazine of Natural History, XI.

1858. Holmes, Postpleiocene Fossils of South Carolina.

1858. Conrad, Proceedings, Academy of Natural Sciences, Philadelphia, IX.

1860. Мӧвсн, Malakozoologische Blätter, VI.

1861. Fischer, Journal de Conchyliologie, IX.

1863. Jefrreys, British Conchology, II.

1864. Carpenter, Report to the British Association for 1863.

1864. Krebs, West Indian marine shells.

1865. Dunker, Novitates Conchologicæ, Mollusca Marina.

1865. Carpenter, Proceedings of the Zoological Society of London.

1865. ConRad, American Journal of Conchology, I.

1866. GABB, Paleontology of California, I, part 1.

1866. Conrad, American Journal of Conchology, II.

1869. Recluz, Actes Soc. Linn., de Bordeaux, XXVII.

1870. Verrill, American Journal of Science, XLIX, March.

1870. M. SARs, Christianiafiordens Fauna, II.

1873. GABB, Topography and Geology of Santo Domingo.

1873. Verrill, Report on the Invertebrate Animals of Vineyard Sound.

1874. Monterosato, Journal de Conchyliologie, XXII.

1875. Conrad, (in) Kerr, Geol. Report of North Carolina, appendix.

1876. Jeffreys, Annals and Magazine of Natural History, XIX.

1876. Meek, Palæontology of the Upper Missouri.

1876. Crosse, Journal de Conchyliologie, XXIV.

1877. Guppy, Sketch of the Marine Invertebrate Fauna of the Gulf of Paria.

1877. Friele, Nyt Magazin for Naturvidenskaberna.

1878. Arango, Contr. a la fauna Malac. Cubana, 1878-1880.

1878. G. O. SARs, Moll. Reg. Areticæ Norvegiæ.

1878. Poulsen, (Mörch) Catalogue of the West India shells in the collection of Dr.

C. M. Poulsen.

1880. Verrill and Smith, Transactions of the Connecticut Academy of Sciences, V.

1880. Von Martens, Beitr. zur meeresfauna der Insel Mauritius und der Seychellen.

Mollusken.

1880. Verrill, Proceedings of the U. S. National Museum, III.

1881. E. A. Sмiтh, Proceedings of the Zoological Society of London.

1881. Jeffreys, Proceedings of the Zoological Society of London.

1881. Brugnone, Bullettino Soc. Malac. Italiana, VI.

1881. Dall, Bulletin, Museum of Comparative Zoology, IX, No. 2. (July, Nov.)

1882. Cossmann, Journal de Conchyliologie, XXX.

1882. Dunker, Index Molluscorum Maris Japonici.

1883. Monterosato, Nomenclatura Conchiglie Mediterranee.

1885. De Gregorio, Bullettino Soc. Malac. Italiana, Pisa, V.

1885. E. A. Sмrтн, Challenger Expedition, Report on the Lamellibranchiata.

1885. Fischer, Manuel de Conchyliologie.

1885. Verrill, Transactions Connecticut Academy of Sciences, VI.

1886. Dall, Bulletin, Museum of Comparative Zoology, XII, No. 6.

1887. Cossmann, Catalogue Illustré des Coquilles Fossiles de l'Eocene des environs de Paris, II.

1887. Fischer, Manuel de Conchyliologie.

1887. Barrois, (in) Zittel, Traité de Paléontologie, II. 
1889. Dall, Proceedings, U. S. National Museum, XII, No. 773.

1889. Dall, Bulletin, U. S. National Museum, No. 37.

1889. Heilprin, The Bermuda Islands.

1890. Stearns, Proceedings, U. S. National Museum, XIII, No. 813.

1891. Pilsbry, List of Mollusca collected by Frederick Stearns in Japan.

1893. Bush, Bulletin, Museum of Comparative Zoology, XXIII, No. 6.

1895. DALL, The Nautilus, IX, No. 7.

1896. Locard, Annales de l'université de Lyon, Campagne du Caudan.

1896. Dall, The Nautilus, X, No. 5, September.

1898. Verrill and Bush, Proceedings, U. S. National Museum, XX, No. 1139.

1898. Locard, Expéditions scientifiques du Travailleur et du Talisman, II.

1898. Bucquoy, Dautzenberg et Dollfus, Mollusques Marins du Roussillon, II.

1898. Posselt, Conspectus Fauna Grönlandiæ.

1899. DaLL, Transactions Wagner Free Institute of Science, III, part 5.

1899. Grzyвowski, Neuen Jahrbuch für Mineralogie, Beilageband, XII.

1901. Dall and Simpson, Report on the Mollusks of Porto Rico.

\section{Family THYASIRID A.}

(Cryptodontidæ of authors.)

Genus THYASIRA Leach.

This is Thyasira Leach (in Lamarck, 1818); Thyatira Jeffreys, 1839, not Hübner, 1816; Bequania Leach (in Brown, 1827); Axinus J. Sowerby, 1821, not Axina Kirby, 1817; Cryptodon Turton, 1822; Clausina Jeffreys, 1847, not Brown, 1827; Ptychina Philippi, 1836; Cryptodon ${ }^{1}$ (Turton) Dall, 1889, not of Conrad, 1837; Schizothwerus Locard, 1898, not of Conrad, 1853; Philis Fischer, 1861; Conchocele Gabb, 1866; Megaximus Brugnone, 1881; Aximulus Verrill and Bush, 1898; Axinodon Verrill and Bush, 1898; and Lucina (sp.) of various earlier authors.

The genus is divisible as follows:

Section Thyasira s. s.

Valves with edentulous hinge, the anterior dorsal area more or less impressed, the posterior more or less distinctly radially sulcate or plicate.

Type, Tellina flexuosa Montagu, 1803, + Venus simuosa Donovan, 1801, not of Pennant, 1777; + Lucina sinuata Lamarck, 1818; + Ptychina biplicata Philippi, 1836; + Cryptodon bisinuatus S. Wood, 1840; + Axinus sinuatus Philippi, 1845. North Atlantic south to the Azores and Mediterranean.

Philis Fischer, intergrades with the other species. Megaxinus Brugnone, differs only by more solid shell and larger nymphs.

Section Aximulus Verrill and Bush, 1898.

Shell minute, ovate or oblong, with the dorsal areas obsolete.

These forms intergrade imperceptibly with those of the previous section; Axinodon Verrill and Bush, appears to differ by no substantial characters.

1 "Cryptodon" moseleyi and luzonicus Smith, do not belong in this family and their place is uncertain. 


\section{Genus AXINOPSIS G. O. Sars, 1878.}

Valves with one or more cardinal teeth; shell small, solid, with no posterior dorsal area or plication, usually suborbicular.

Type, A. orbiculatus Sars, 1878; not Lucina orbiculata Montagu, 1808 (as Venus); + Kellia orbicularis Friele, 1877, not of Searles Wood, 1853.

Genus LEPTAXINUS Verrill and Bush, 1898.

Shell like Axinulus, but with distinct lateral teeth.

Type, L. minutus Verrill and Bush, 1898.

\section{? Genus LUDOVICIA Cossmann, 1887.}

Valves rounded-triangular, subcompressed, edentulous, with minute prominent umbones.

Type, L. squamula Cossmann, 1887, Parisian Eocene.

It is possible that further researches may render it advisable to include Montacuta in this family.

\section{SPECIES OF THE EAST AMERICAN COAST.}

THYASIRA INSIGNIS Verrill and Bush (as Cryptodon), I898.

Grand Banks of Newfoundland to Cape Cod, Massachusetts, in 65 to 471 fathoms.

Cryptodon Sarsii Verrill, 1880, not of Philippi, 1845, is synonymous.

THYASIRA OVOIDEA Dall (as Cryptodon), r889.

Off Cape Fear, North Carolina, in 563 fathoms. $^{1}$

THYASIRA GRANDIS Verrill (as Cryptodon), 1885.

From latitude $38^{\circ} 29^{\prime}$ north, south to Yucatan Straits, on the American coast in 856 to 1,582 fathoms. Also on the coast of France in 820 fathoms.

Cryptodon pyriformis Dall, 1886, and Schizotharus grandis Locard, 1896, are synonymous. The application of the name Schizotharus to this species by Locard doubtless grew out of a confusion of Cryptodon Conrad, 1837 (= Schizotharus Conrad, January 31, 1853, = Tresus Gray, January 1, 1853) with Cryptodon Turton, 1822.

THYASIRA GRANULOSA (Jeffreys as Axinus) Monterosato, 1874 .

Gulf of Mexico to Santa Lucia Island, West Indies, in 60 to 116 fathoms. Also Mediterranean, Bay of Biscay, and Canaries, in 49 to 645 fathoms.

${ }^{1}$ Figured in Proc. U. S. Nat. Mus., XII, pl. xIv, fig. 3.

Proc. N. M. vol. xxiii- 50 
Aximus orbiculatus Jeffreys, 1881 (not Axinopsis orbiculatus Sars, 1878 ) is synonymous. Its identity with the Sicilian fossil Verticordia orbiculata ${ }^{1}$ although claimed by Jeffreys, is very doubtful, and Jeffreys' figures of the sculpture are probably taken from the fossil and not from the recent shell, agreeing much better with the former and not at all with the surface of his types in the U. S. National Museum.

THYASIRA PLICATA Verrill (as Cryptodon), 1885.

Off Marthas Vineyard, Massachusetts, in 1,073 to 1,122 fathoms.

THYASIRA GOULDII Philippi (as Axinus), r 845 .

Greenland to Stonington, Connecticut, in 5 to 400 fathoms; also on the west coast of America in Bering Sea, south of Bering Strait, and southward to the Queen Charlotte Islands.

Lucina flemosa Gould, 1841, but not of Montagu, 1805; and Thyasira hyalina ${ }^{2}$ Mörch, ${ }^{3} 1857$, are synonymous.

THYASIRA SARSII Philippi (as Axinus), 1845 .

Greenland according to Posselt; ${ }^{*}$ Norway, Spitsbergen, Iceland; Sars and others.

THYASIRA TRISINUATA d'Orbigny (as Lucina), 1846.

Labrador to Martinique, in 15 to 192 fathoms, North Atlantic, Vigo Bay, and Mediterranean, Jeffreys; also Sitka Harbor, Alaska, in 10 fathoms, and on the coast of Korea, by Captain St. John, R. N.

Axinus flexuosus var. polygona Jeffreys, ${ }^{5} 1863$, and Cryptodon obesus Verrill, 1872, are synonymous, and perhaps Lucina flexuosa of Beau's catalogue of the shells of Guadeloupe.

THYASIRA FUEGIENSIS Dall (as Cryptodon), I889.

Magellan Strait, in 77 fathoms; also on the west coast of Patagonia, in 449 fathoms.

A large and feebly plicated species, recalling T. sarsii Philippi. ${ }^{6}$

THYASIRA PLANA Verrill and Bush (as Cryptodon), r898.

Halifax, Nova Scotia, to Cape Cod, Massachusetts, in 8 to 100 fathoms.

Approaching the young of $T$. sarsii, but none of the size of adult sarsii have been obtained from the American coast south of Greenland.

THYASIRA IN EQUALIS Verrill and Bush (as Axinulus), r898.

Halifax, Nova Scotia, to Cape Cod, Massachusetts, in 14 to 49 fathoms.

Distinctly plicate behind, and therefore not an Axinulus.

\footnotetext{
${ }^{1}$ Seguenza, Vert. Plio. Ital., 1876, p. 9.

${ }^{2}$ Beck manuscript, 1847.

${ }^{3}$ In Rink's Greenland.

${ }^{4}$ Co_ssp. Fauna Grönl., 1898, p. 80.

${ }^{5}$ Brit. Conch., II, p. 248.

${ }^{6} \mathrm{It}$ is figured in Proc. U. S. Nat. Museum, XII, pl. xIv, fig. 2.
} 
THYASIRA CONIA Dall and Simpson, Igor.

Off San Juan de Porto Rico, in 310 fathoms.

THYASIRA CROULINENSIS Jeffreys (as Clausina), I847.

West Greenland, in 199 fathoms, Posselt; off Bermuda, in 435 fathoms, Challenger expedition; North Atlantic, Norway to the Azores, in 30 to 1,012 fathoms.

Axinus pusillus M. Sars (manuscript?) is said by G. O. Sars to be synonymous.

THYASIRA EQUALIS Verrill and Bush (as Cryp:odon), I898.

Nova Scotia to Chesapeake Bay, in 94 to 1,537 fathoms.

Cryptodon croulinensis var. altus Verrill and Bush, 1898, differs, according to the types, from this species by a longer and straighter anterior slope, but this character is shown by a large series to be inconstant. It occurs in the Gulf of Maine and south to Cape Cod, in 14 to 35 fathoms.

THYASIRA ROTUNDA Jeffreys (as Axinus), I88r.

Abyssal in the North Atlantic, and liable to be found in deep water on the American coast.

Axinus flexuosus var. rotunda Jeffreys. ${ }^{1}$ This form is near to $T$. equalis Verrill and Bush, but is less truncate behind.

THYASIRA (AXINULUS) BREVIS Verrill and Bush, 1898.

Georges Banks, off Cape Cod, and south to the coast of North Carolina, in 100 to 1,825 fathoms.

Cryptodon obsoletus Verrill and Bush, 1898, is identical with this species, and the differences in the figures, especially as to the position of the ligament, are due to a misconception of the artist and the translucency of the very minute shell.

THYASIRA (AXINULUS) FERRUGINOSA Forbes (as Kellia), I844.

Arctic seas, North Atlantic south to North Carolina on the west, and the Azores, Mediterranean, Adriatic, and the Morea on the east, in 20 to 1,525 fathoms; also in Bering Sea, Krause.

According to Jeffreys the Kellia transversa Forbes (1844, Aegean) and the Axinus oblongus Monterosato are the young of this species, which is relatively more transverse than the adult, and the same is probably true of the types of Cryptodon (Axinulus) ovatus Verrill and Bush, 1898, which in addition are abnormally modified by an excessive load of oxide of iron. Specimens purporting to be the same, from station 2113, U. S. Fish Commission, are apparently identical with $T$. 
fermuginosa. The name of this species appears in the Moll. Marins du Roussillon, 1898, page 805, as Aximus "fermugineus" Forbes.

THYASIRA (AXINULUS) CYCLADIA S. Wood (as Kellia), r853.

Baffins Bay, in 1,750 fathoms, Valorous expedition; North Atlantic and Mediterranean, 3,038 fathoms.

Poromya subtrigona Jeffreys, 1858, is identical.

THYASIRA (AXINULUS) EUMYARIA M. Sars (as Axinus), I870.

Baffins Bay, 1,100 fathoms, Valorous expedition; Norway and Mediterranean, in 200 to 1,456 fathoms.

THYASIRA (AXINULUS) SUCCISA Jeffreys (as Axinus), 1876.

Off Fernandina, Florida, in 294 fathoms; North Atlantic, 92 to 1,366 fathoms; Mediterranean, 40 to 120 fathoms.

This is perfectly distinct from Aximus incrassatus Jeffreys, 1876 (=Leptaximus sp.) of which Jeffreys regarded it as a variety.

THYASIRA (AXINULUS) ELLIPTICA Verrill and Bush, I898.

Off Marthas Vineyard, Massachusetts, in 1,451 fathoms.

This is Axinodon ellipticus Verrill and Bush, a species near $T$. cycladia S. Wood, but more rounded behind. The resilium is thicker and expanded behind on its ventral aspect, but is not internal in the strict sense of being occluded by the shell dorsally. A microscopic nodulation under the beaks does not seem to differ, except in being much smaller, from the occasional nodulations frequently found in typical Thyasira in the same region. Only one specimen is known, and the evidence seems quite insufficient to separate it from Axinulus as yet.

?THYASIRA (AXINULUS) SIMPLEX Verrill and Bush, I898.

Casco Bay, Maine, to Marthas Vineyard, Massachusetts, in 349 fathoms.

This has the aspect of a nepionic shell and may even not belong to this family.

? THYASIRA (AXINULUS) PYGM ÆA Verrill and Bush, I898.

Halifax, Nova Scotia, to Marthas Vineyard, Massachusetts, in 206 to 499 fathoms.

Possibly the young of ferruginosa. At all events, it has the appearance of a nepionic shell and requires confirmation to rank as a species.

? THYASIRA (AXINULUS?) species indeterminate.

Off Bermuda, in 450 fathoms, Challenger expedition.

An undetermined species, reported by E. A. Smith in his report on the Challenger Pelecypoda, page 195, 1885. 


\section{AXINOPSIS ORBICULATUS G. O. Sars, I878.}

Greenland and Cumberland Sound, south to Casco Bay, Maine, 10 to 30 fathoms; Arctic Ocean and northern Norway, 8 to 120 fathoms, but not on the Pacific side.

A variety incequaiis Verrill and Bush, 1898, found in 18 to 26 fathoms from the Bay of Fundy to Cape Ann; is more quadrate, less orbicular, and all the specimens examined are smaller than the adult $A$. orbiculatus. A large proportion of all those dredged by the U. S. Fish Commission, when compared with those from the high north, appear to be immature. The forms referred to this species from the Pacific coast as far as examined all belong to other species of the genus.

AXINOPSIS CORDATA Verrill and Bush, I898.

Marthas Vineyard to Cape Hatteras, North Carolina, in 43 to 202 fathoms.

Extremely close to those Thyasiras which have the proximal end of the indented anterior hinge line slightly thickened.

LEPTAXINUS MINUTUS Verrill and Bush, I898.

Off Marthas Vineyard, in 100 fathoms; easily identified by the distinct lateral laminæ.

LEPTAXINUS INCRASSATUS Jeffreys (as Axinus), I876.

Baffins Bay and North Atlantic, in 1,480 to 1,785 fathoms; north of Ireland, in 1,180 fathoms. A variety (?) off Culebra Island, West Indies, in 390 fathoms, Challenger expedition.

Jeffreys's original type is figured as exhibiting denticulations which probably belong to a provinculum. His specimens in the U. S. National Museum do not show it, but are evidently referable to Leptaximus. His variety succisa, however, is a distinet species of Axinulus.

Note.-The shell described by Reeve in 1850 as Lucina barbata was doubtfully referred to Cryptodon by E. A. Smith, in his report on the Challenger bivalves. That gentleman now thinks this identification questionable, as it was founded on a single imperfect valve which may find a place in Lucina, properly so called. Both shells are probably true Lucinas and the Challenger valve may be a drifted young specimen of L. philippiana Reeve.

SPECIES OF THE PACIFIC COAST OF AMERICA.

THYASIRA BISECTA Conrad (as Venus), 1849.

Gulf of Alaska and Puget Sound, in 69 to 135 fathoms. Also in the later Tertiaries of California as far south as San Pedro.

This is Cyprina bisecta Conrad, 1865, and Conchocele disjuncta Gabb, 1866. It is the largest species of the genus, measuring up to $80 \mathrm{~mm}$. 
in extreme length, but shows absolutely no characters which might separate it from its smaller congeners. It was first described from the Miocene of Astoria; later turned up in the Pliocene of San Pedro (not the Post-Pliocene, as stated by Gabb) and lastly was dredged by the U. S. Fish Commission and the Young Naturalists' Society of Seattle, in Puget Sound. ${ }^{1}$

THYASIRA GOULDII Philippi (as Axinus), 1845 .

Metchigme Bay, Bering Strait, south to Sitka Harbor, the Queen Charlotte Islands, and Puget Sound, in 8 to 111 fathoms. Also on the Atlantic coast and in the Pliocene of San Pedro, California, at Dead Mans Island; Arnold.

See the Atlantic list for further data.

THYASIRA TRISINUATA d'Orbigny (as Lucina), 1845 .

Sitka Harbor, 10 fathoms; also on the Atlantic coast and the coast of Korea.

See the Atlantic list for further data.

THYASIRA BARBARENSIS Dall (as Cryptodon), I889.

Coast of Washington, south to the Gulf of California, in 16 to 559 fathoms.

Recalling $T$. sarsii, but differently proportioned. The specimens named Axinus flexuosus by Cooper, from 120 fathoms, near Catalina Island, California, prove to belong to this species. ${ }^{2}$

THYASIRA EXCAVATA Dall, rgor.

Oregon to the Gulf of California in 66 to 1,005 fathoms.

A well-marked species notable for the sharp fluting of the posterior dorsal area. See notes and descriptions.

THYASIRA TOMEANA Dall, rgor.

Tomé, Chile, in 10 fathoms. See notes and descriptions.

THYASIRA MAGELLANICA Dall, Igor.

West coast of Patagonia in 194 to 348 fathoms. See notes and descriptions.

THYASIRA FUEGIENSIS Dall (as Cryptodon), r889.

West coast of Patagonia and in Magellan Strait in 77 to 449 fathoms. See the Atlantic list for other data.

${ }^{1}$ It is figured in Proc. U. S. Nat. Museum, XVII, 1895, pl. xxvI, figs. 2 and 5.

${ }^{2}$ It is figured in Proc. U. S. Nat. Museum, XII, 1889, pl. vin, fig. 9. 
THYASIRA (AXINULUS) FERRUGINOSA Forbes (as Kellia), i844.

Aleutian Islands in 60 fathoms; Krause.

See the Atlantic list for further data.

AXINOPSIS VIRIDIS Dall, Igor.

Plover Bay, Bering Strait, southward to Catalina Island, California, on the east, and to northern Japan (Capt. St. John, R. N.) on the west, in 5 to 167 fathoms.

A silky green, solid, orbicular species with very distinctly developed cardinal teeth. See notes and descriptions.

\section{AXINOPSIS SERICATUS Carpenter (as Cryptodon), I864.}

Kyska Island, Aleutians, south to Puget Sound and Catalina Island, California, in 2 to 120 fathoms.

More ovate, flatter and thinner, with a less developed dentition and pale yellow periostracum. The name was misprinted serricatus in the British Association Report of 1863 . See notes and descriptions.

\section{Family DIPLODONTID A Dall.}

This family is composed of Lucinoid shells, in which the external limb of the gills is developed, reflected, and sometimes appendiculate, the adductor scars not projecting into the disks of the mantle, the hinge with the laterals obscure or absent, the valve margins plain, the shell suborbicular in outline, rarely nestling and irregular. The foot is elongated, cordlike, and more or less distally clavate in the typical forms, but may be nearly normal in the estuarine Joannisiella, affording a parallel to Jagonia in the Lucinida. Thoughout the family the dental formula is $\frac{\mathrm{L} 0.1010 .0}{\mathrm{R} 0.0101 .0}$, the central cardinals being usually bifid.

The fossil genus Sphceriola has much the appearance externally of Diplodonta, but the shell is heavy, and the hinge edentulous, and its relations to this family remain to be made out. The genus Taras Risso, from the figure and description, ${ }^{1}$ would seem to be a Diplodonta, in which the delicate posterior cardinal of the left valve had been broken away and the corresponding tooth of the right valve mistaken for an adjacent lateral. It was founded on $T$. antiquatus Risso, a fossil of La Trinité (Tertiary). If this identification proves correct, the name Taras will supersede Diplodonta, being five years earlier in date. It was placed next to Loripes by Risso. I do not make the substitution, hoping that some Italian naturalist may be able to examine Risso's type species, and thus arrive at certainty before upsetting an old and familiar name.

${ }^{1}$ Hist. Nat. Eur. Mér., IV, 1826, p. 344, pl. xII, fig. 167. 
The family comprises the following genera:

DIPLODONTA Bronn, 1831.

Type, Venus lupinus Brocchi.

UNGULINA Daudin, 1802.

Type, U. rubra Roissy.

FELANIA Recluz, 1851.

Type, Venus diaphana Gmelin.

JOANNISIELLA Dall, 1895.

Type, Cyrenella oblonga Sowerby.

Of these genera only Diplodonta is represented in American waters, as far as yet known, and it is divisible into the following groups:

Section Diplodonta s. s. Type, D. lupinus Brocchi.

Section Felaniella Dall, 1899. Type, Felania usta Gould.

Shell like Diplodonta, but heavy, compressed, smooth externally, with a conspicuous usually dark periostracum and less equilateral valves.

This group exists well developed in the Eocene. The species called Felania by Carpenter, from American waters, are included in it. The type is from Japan.

Section Phlyctiderma Dall, 1899. Type, Diplodonta semiaspera Philippi.

Shell like Diplodonta, except that the surface, in addition to incremental sculpture, is punctate, pustulate or subreticulate. The type is from Cuba, but the group is world wide.

Section Sphorella Conrad, 1838. Type, S. subvexa Conrad= Erycina subconvexa d'Orbigny 1852, not Lucina subvexa Conrad, 1848.

Shell large, concentrically striate, an impressed line above the anterior cardinal, suggesting a minute lunule; the right posterior cardinal wide, undulated above, the posterior adductor scar distant from the hinge plate. The type is Miocene, and there is one recent species known from the Atlantic coast; D. Verrilli Dall, 1900.

\section{Genus UNGULINA Daudin.}

This is Ungulina Daudin, ${ }^{1}$ sole example U. rubra Roissy ${ }^{2}$ and Clotho Basterot, 1825, not Faujas St. Fond, 1808.

The type is Tellina cuneata Spengler, ${ }^{3}$ but not of d'Orbigny, 1845 . This specific name must be adopted in place of the more familiar rubra of Roissy. The Ungulina transversa of Lamarck, ${ }^{4}$ is united by Deshayes with Lamarck's $U$. oblonga, and both are identical with

${ }^{1}$ Bose, Hist. Nat, Coq., III, 1802, p. 86.

${ }^{2}$ Idem, pl. $\mathrm{xx}$, figs. $1,2$.

${ }^{3}$ Chemnitz, Conch. Cab.VI, 1782, p. 135, pl. xiII, fig.131.

${ }^{4}$ Animaux sans Vertébres, V, 1818, p. 487. 
U. rubra Roissy ${ }^{1}$ and the earlier cuneata of Spengler. Conrad ${ }^{2}$ reported the presence of this species in a mass of coral rock containing many West Indian boring mollusks, but this discovery has not been confirmed by any subsequent collector or explorer, though in itself not inherently improbable. In the absence of confirmatory evidence we can not regard the presence of Ungulina cuneata in the American or West Indian fauna as sufficiently established.

No species of Felania in the correct sense, or of Joannisiella, are known from the Western Hemisphere.

\section{LIST OF EAST AMERICAN SPECIES.}

\section{DIPLODONTA TORELLI Jeffreys, I876.}

North Atlantic, southeast of Greenland, in 1,450 fathoms. Spitsbergen, in moderate depths of water. Also Aleutian Islands.

A rude, chalky species of large size, which may perhaps be found later on the Labrador coast. The figure of Lucina lencophoata Reeve, 1850 , somewhat resembles this species.

DIPLODONTA PUNCTATA Say, 1822.

Cape Hatteras, North Carolina, to Rio de Janeiro, Brazil, in 14 to 124 fathoms, southward to the Straits of Magellan, and thence north to Chiloe Island.

This is Amphidesma punctata Say, 1822; Lucina guaraniana d'Orbigny, 1846; Lucina venezuelensis Dunker, 1848; L. janeirensis Reeve, 1850; L. subglobosa C. B. Adams (1847), 1852; L. brasitiensis Mittré, 1850 (but not L. brasitiana d'Orbigny, 1846, or brasitiensis Philippi, 1850); Diplodonta Phillippii Huppé, 1854, and Mysia pellucida Heilprin, 1889.

This is a plain, globose shell, with feeble incremental sculpture and microscopic radial striæ. The anterior end is somewhat attenuated and the posterior expanded. The young are often nearly orbicular. The specific name is derived from the punctation visible on the disk, internally in many specimens. It appears to pass through Magellan Strait and reach as far north as the island of Chiloe, on the Pacific side of South America.

\section{DIPLODONTA NUCLEIFORMIS Wagner, 1838.}

Cape Hatteras, North Carolina, to Porto Rico and St. Thomas, West Indies, in 15 to 52 fathoms.

This is Mysia nucleiformis of Wagner; Loripes elevata Conrad, 1845; Cytherea spharica H. C. Lea, 1845; Diplodonta elevata Conrad, 1858, and Mysia carolinensis Conrad, 1875.

It is a small, suborbicular, globose species, which goes back to the Oligocene in time.

${ }^{1}$ Sonnini's Buffon, Moll. VI, 1805, p. 575, pl. LXvi, fig. 4.

${ }^{2}$ Amer. Jour. Sci. XXIII, no. 2, 1833, p. 345. 
DIPLODONTA PORTEZIANA d'Orbigny, 1846.

Rio de Janeiro, Brazil, and adjacent region. This is probably the same as Lucina leucophreata Reeve, 1850.

DIPLODONTA PATAGONICA d'Orbigny, 1842.

Near Rio de Janeiro, Brazil, in 59 fathoms, south to San Blas Bay. DIPLODONTA (FELANIELLA) CANDEANA d'Orbigny, I846.

Belize to Brazil, in 2 to 25 fathoms.

DIPLODONTA (FELANIELLA) VILARDIBOANA d'Orbigny, i 846.

Coast of Argentina, in 11 fathoms.

DIPLODONTA (PHLYCTIDERMA) SOROR C. B. Adams, 1852.

Texas coast to Jamaica. Pleistocene in South Carolina.

D. kiawahensis Holmes, 1858, is synonymous.

DiplodontA (PHLYCTIDERMA) NOTATA Dall and Simpson, rgor.

Marco, Florida, to Porto Rico.

Like $D$. candeana, but profusely punctate.

DIPLODONTA (PHLYCTIDERMA) SEMIASPERA Philippi, 1836 .

Cape Hatteras, North Carolina, to Cape San Roque, Brazil, in 14 to 20 fathoms.

Lucina granulosa C. B. Adams, 1845, and Dunker, 1853; L. semireticulata (part) d'Orbigny, 1846 , are synonymous.

DIPLODONTA (PHLYCTIDERMA) SEMIRETICULATA d'Orbigny, 1846.

San Sebastian, Brazil, and southward to the coast of Uruguay and Argentina in 11 fathoms.

D. semireflecta Krebs, 1864 (lapsus) and D. platensis Dall, 1899, are synonymous. D'Orbigny confused this and the last species under one name, though noting the differences (in 1853) between the Argentine and Antillean forms; but the figure given in the original publication is of the Argentine type, and I have therefore restored his name. The Antillean shell is more globular, smaller, and usually with the sculpture in separate granules or pustules, while that of the Argentine form is more like the reticulations of a stretched net.

DIPLODONTA (PHLYCTIDERMA) PUNCTURELlA Dall, i899.

Jamaica, Porto Rico, St. Thomas, and receding to the Oligocene. 
DIPLODONTA (SPHÆRELLA) VERRILLI Dall, I899.

From Marthas Vineyard, Massachusetts, to North Carolina, in 15 to 69 fathoms.

This is Diplodonta turgida Verrill and Smith, 1881, not of Conrad, 1848 .

\section{LIST OF WEST AMERICAN SPECIES.}

\section{DIPLODONTA (TORELLI Jeffreys var.?) ALEUTICA Dall, igor.}

Southern part of Bering Sea, from the Pribilof Islands to the Aleutians, and eastward to the Shumagin Islands, in 3 to 13 fathoms.

A chalky, subrectangular species, with coarse epidermis. The young have a smooth surface and dark gray periostracum. The young of Torelli have a yellow periostracum, profusely wrinkled. The adults appear almost identical, though the regions occupied are on opposite sides of the world.

\section{DIPLODONTA ORBELLA Gould, 1852.}

Kadiak Island, Alaska, to the Gulf of California, in 5 to 30 fathoms. Spharella tumida (Conrad, Manuscript) Carpenter, $1863,{ }^{1}$ is synonymous. D. subrugosa Philippi ${ }^{2}$ should be compared with it.

The gills in this species ${ }^{3}$ are all developed, the foot with a short, stout stem, and distally subspherically bulbous; there are two entire siphonal orifices, without siphons, the anal exhibiting a short valve. It is the habit of the animal to form a sort of nest of sand and adventitious matter, cemented by mucus, with long tubular openings, the whole of irregular form, but completely concealing the inmate.

\section{DIPLODONTA SUBQUADRATA Carpenter, I855.}

Catalina Island, California, south to Panama, in 16 to 36 fathoms.

More compressed and thinner than $D$. orbella, and of a different outline. In the description the edge of the excavated hinge plate has been mistaken for a lateral tooth. It is not D. subquadrata Gabb (=D. gabbi Dall), 1873, from the Tertiary of Santo Domingo, West Indies, but is probably referred to ${ }^{4}$ by the name $D$. undata by Carpenter, 1857 .

\section{DIPLODONTA PUNCTATA Say, r822.}

From Magellan Straits northward to the island of Chiloë. See Atlantic list.

${ }^{1}$ Not of Proc. Zool. Soc. London, 1856, p. 215.

${ }^{2}$ Zeitsch. Mal., 1848, p. 183.

${ }^{3}$ External and internal laminæ, direct and reflected, with an appendix.

${ }^{4}$ Mazatlan Catalogue, p. 103. 
DIPLODONTA (FELANIELLA) OBLIQUA Philippi, 1846.

Cape St. Lucas to Guayaquil.

This is Diplodonta obliqua Philippi, 1846, but not Lucina obliqua Philippi, 1850 (April), nor of Reeve (June), 1850, Defrance, 1823, nor Goldfuss, 1841. Lucina calculus Reeve, 1850, is synonymous.

DIPLODONTA INCONSPICUA Philippi, I842.

Island of Chiloe, on the southern coast of Chile.

This is D. inconspicua Philippi ${ }^{1}$ and Huppé. ${ }^{2}$ It is a rude species, with a coarse periostracum, the analogue in the Southern Hemisphere of $D$. torelli var. aleutica Dall in the northern Pacific.

\section{DIPLODONTA (FELANIELLA) SERICATA Reeve, $185^{\circ}$}

Lower California to Panama.

This species varies slightly in outline and convexity, according to its state of growth, and has been described in the Iconica under the names of Lucina cornea, L. nitens, and L. sericata Reeve. Carpenter called it Felaniaserricata $($ sic), by which name it is best known. He labeled some rather convex specimens in the U. S. National Museum L. tellinoides Reeve, but from the best information I can obtain the true L. tellinoides is a Pseridomiltha, as elsewhere indicated.

\section{DIPLODONTA (PHLYCTIDERMA) C $E L A T A$ Reeve, 1850.}

Bay of Guayaquil, Cuming.

This species belongs to the same group as $D$. semirugosa Dall, but differs by its almost internal ligament, larger size, and coarser sculpture.

\section{DIPLODONTA (PHLYCTIDERMA) SEMIRUGOSA Dall, I899.}

Gulf of California to Panama.

This is Diplodonta semiaspera of Carpenter, 1857, but not of Philippi, 1836, which is the West Indian form. The Japanese species which has been called by the same name is now known as D.japonica Pilsbry.

\section{NOTES.}

Lucina (Diplodonta?) capax Carpenter, 1863, page 69, from Panama, appears to be a nomen nudum. Lucina obliqua Philippi, 1850, is an uncertain species, both as to habitat and characters. It is not the Diplodonta obliqua Philippi, 1846. The Lucina punctata mentioned by Carpenter and others as inhabiting Panama is not the Diplodonta punctata Say or the Codakia punctata Linnæus. It was probably intended for the latter, which is not found on the west American coast,

${ }^{1}$ Wiegmann's Archiv., 1842, p. 74.

${ }^{2}$ Gay's Chile, VIII, 1854, p. 357, atlas, pl. viII, fig. 4. 
but is Polynesian. The references to west-coast localities are probably based on Codakia colpoica Dall. L. punctata of Poulsen's catalogue is probably L. orbicularis Linnæus. The Diplodonta semiaspera of Carpenter in the Mazatlan catalogue was a compound of several species. His variety discrepans is indeterminable. A pencil sketch of it in my possession, made by Carpenter, looks not unlike the young of Diplodonta orbella Gould.

\section{Family LUCINID A.}

This family differs from the Diplodontida by its less perfectly developed gills; from the Thyasirida by the inclusion within the general mass of the body of the hepatic and sexual glands, and also by the gills being less developed; from the Corbida by the general shell characters and the loriform anterior adductor scars prolonged into the area of the disk. The branchial orifice is usually incomplete, and the anal is supplemented by a greatly developed introvertible tube, corresponding to the "valve" of an ordinary Teleodont siphon, and usually supposed to be, but actually not, homologous with a true siphon. If, as seems possible, the Silurian Prolucina is a true Lucinoid, this is one of the few families of Teleodonta which are represented in the Silurian, but the characteristics of Prolucina are not yet fully elucidated. Excluding pre-Tertiary groups, the family contains the following genera:

CODAKIA Scopoli, 1777.

LUCINA Lamarck, 1799.

LORIPES Cuvier, 1817.

MYRT $A$ A Turton, 1822.

PHACOIDES Blainville, 1825.

DIVARICELLA von Martens, 1880.

These groups and their subdivisions will be taken up serially.

Genus CODAKIA Scopoli.

This is Codakia Scopoli, 1777; Orbiculus (sp.) Megerle, 1811 (not Orbicula Lamarck, 1799); Lentillaria Schumacher, 1817; Lenticularia Gray, 1847; Ctena Mörch, 1860 (not Ctenia Lepel. et Serv., 1825, Lepidoptera); Jagonia Recluz, 1869; Antilla de Gregorio, 1885 (not Antillia Duncan, 1864, Corallia); Codakia Fischer,1887, and Lintellaria, Bucquoy, Dollfus, and Dautzenberg, 1898 (err. typ. pro Lentillaria).

This is a well-marked genus which may be divided as follows:

Codakia s. s. Shell large and heavy with more or less distinctly reticulate sculpture, valves white externally, if colored the color is internal and chiefly marginal; with small beaks and lunule, not inflated, 
the ligament and resilium large, deeply inset, the former with an external calcareous coating; margins entire; foot moderately elongated but not loriform.

Dental formula: $\frac{\text { L lol. 1010. Iol }}{\text { R olo. 0101. olo }}$ Type, Chama codok Adanson.

The posterior lateral teeth are obscured by the growth of the ligament in the adult, but traces of them can almost always be noted. The cardinals are not bifid and the anterior right cardinal is often obscured by the excavation of the lunule in front of it in the adult.

Jagonia Recluz. Shell smaller, lighter, frequently tumid and very inequilateral; beaks more prominent and the lunule, relatively, often larger; ligament and resilium external, on a narrow nymph, not coated with shelly matter; posterior laterals distinct; margins usually crenulate; foot differing little from the ordinary Pelecypod type. Type, Le jagon Adanson, = Venus orbiculata Montagu + Lucina pecten Lamarck.

In these forms the radial part of the sculpture is relatively more pronounced than in Codakia. The name Ctena of Mörch would have precedence over Jagonia if not regarded as preoccupied by the prior use of Ctenia in entomology.

In the typical division of the genus $C$. punctata and $C$. tigerina Linnæus (as Venus, 1758) are East Indian and Indo-Pacific, C. orbicularis Linnæus is Antillean, and a distinct species, here described, is found on the Pacific coast. These have been lumped together by most writers hitherto to the great confusion of the nomenclature; though, as Hanley pointed out half a century ago, Linnæus himself originally discriminated the three first mentioned and assigned the true localities to them; though he afterwards confounded the second and third. A similar confusion has, with more excuse, attended the names of the more common species of Jagonia. ${ }^{1}$

It is possible that when we know more about them some of the small species, here referred to, Jagonia may require a separate section for

${ }^{1}$ The Mediterranean species, long confounded with the Lucina pecten of Lamarck, is the Tellina reticulata of Poli, 1798, not of Linnæus, 1766; the Lucina reticulata of Payraudeau, 1826, not of Lamarck, 1818 (=Semele sp.); the Lucina squamosa and pecten of authors, but not of Lamarck; the Lucina decussata of Costa, 1830; and, according to Dautzenberg (Moll. de Roussillon) the Lucina carnaria and mirabilis of Locard, 1892. The latter is not the L. mirabilis of Dunker, 1865, which is Miltha Voorhovei Deshayes, 1857, from Mozambique. The Mediterranean shell must then take the name of Codakia (Jagonia) decussata (Costa).

The common Indo-Pacific species has almost as complex synonymy, having been first described from specimens probably collected at the Sandwich Islands by Nuttall, but erroneously referred (like some other species of Nuttall) to San Diego, California, where no Jagonia exists. It is the Lucina bella Conrad, 1837, not of Carpenter, 1857; L. fibula (part) Reeve, $1850 ;$ L. ramulosa Gould, $1850 ;$ L. divergens of Philippi, 1850; and has been referred to L. squamosa and L. pecten of Lamarck by many authors. The name Codakia (Jagonia) bella (Conrad) must be retained for it. 
their reception, but for the present this seems unjustified. The East American species are as follows:

CODAKIA ORBICULARIS Linnæus, 1758.

From St. Augustine, Florida, southward to the Keys; at Bermuda; also on the west coast of Florida north to Little Sarasota Bay; Texas; East Mexico; throughout the West Indies as far as Maceio, Brazil; (Senegal?). In 1 foot water, among algæ, Krebs.

This is the Venus orbicularis of Linnæus, 1758; V.tigerina (part), Linnæus, 1766; Cytherea tigerina Lamarck, ex parte, 1818, but not C. tigrina Lamarck, 1818; Lucina tigerina Reeve, 1850, not of Linnæus, 1758; Lucina pusilla Gould (nepionic shell), 1862; but not Lucina orbicularis Sowerby, 1837, nor Deshayes (Morea) 1836. Venus incrustata Linnæus, 1758, is supposed by Dillwyn to be based on an artificially polished specimen of this group.

\section{CODAKIA CUBANA Dall, rgor.}

Gulf of Mexico, at station 36, in 84 fathoms, U. S. Coast Survey steamer Blake.

A small, thin, and delicate species, with obsolete sculpture, as becomes its rather deep-water habitat. It was erroneously identified with Lucina lenticula Reeve, in the Blake Report of 1886.

\section{CODAKIA (JAGONIA) ORBICULATA Montagu, i808.}

This species was first described by Montagu from an adventitious specimen supposed to be British. It is the Venus orbiculata Montagu, 1808, and Dillwyn, 1817; Lucina squamosa Lamarck, 1818, not of Lamarck, 1806; Lucina pecten Lamarck, 1818 (not of many authors); Lucina imbricatula C. B. Adams, 1845; Lucina occidentalis Reeve, 1850; Lucina obliqua Reeve, 1850 (according to E. A. Smith), but not of Defrance, 1823, or Philippi, 1850; Lucina pectinata C. B. Adams, 1852, not of Gmelin, 1792, or Carpenter, 1857; L. nasuta Guppy (erroneously as of Conrad), 1887; but not Lucina orbiculata Nyst, of the Belgian Tertiaries. Guppy's name is probably an error for $L$. nassula Conrad, which belongs in a totally distinct group.

This type appears to be very variable and to extend its range from Senegal and the Azores to the east coast of America and the Antilles. The following forms may be discriminated:

\section{JAGONIA ORBICULATA var. ORBICULATA Montagu.}

Cape Lookout, North Carolina, and Bermuda, south to the West Indies, the Abrolhos Islands and San Sebastian, Brazil; from low water to 52 fathoms: Senegal, Azores.

This is the common form in which the sculpture is of rather strong ribs radiating from the umbones and more or less divaricate toward 
the ventral margin, but not spinose or imbricate. It is $L$. occidentalis Reeve and L. pectinata C. B. Adams.

JAGONIA ORBICULATA var. FILIATA Dall, igor.

Florida Keys, Bermuda, and southward to Cuba and Yucatan, in 85 to 300 fathoms.

This is the deep-water type with obsolete sculpture and entire, not divaricating, riblets radiating directly to the margin. Reeve's figure of obliqua fairly represents this form.

JAGONIA ORBICULATA var. IMBRICATUlA C. B. Adams.

Jamaica, Santo Domingo, Santa Lucia, Curaçao.

This form has straight, strong ribs, not divaricating, and concentrically, evenly subimbricate.

JAGONIA ORBICULATA var. RECURVATA Dall, Igor.

Florida Keys to Cape San Antonio, in 8 to 300 fathoms.

This form is more plump and the dorsal radials are distally arcuately recurved, meeting the shell margin at right angles.

CODAKIA (JAGONIA) COSTATA d'Orbigny, 1846.

Cape Lookout, North Carolina, southward to Rio de Janeiro, and San Sebastian, Brazil, in 13 to 85 fathoms.

This is Lucina costata d'Orbigny, 1846, but not of Tuomey and Holmes, 1856; L. textilis Philippi, April, 1850, but not of Guppy, 1896; Lucina antillarum Reeve, August, 1850; Lucina ornata C. B. Adams (Manuscript 1847), 1852, but not of Reeve, 1850, nor of Agassiz, 1845 .

This species varies from suborbicular to very inequilateral, but is easily recognizable by its fasciculated riblets and wedge-like shape.

\section{CODAKIA (JAGONIA) PORTORICANA Dall, rgor.}

Mayaguez Harbor and San Juan de Porto Rico, in 20 to 30 fathoms.

A small and inconspicuous species, which is provisionally located in this group.

\section{CODAKIA (JAGONIA?) PECTINELlA C. B. Adams, 1852.}

Jamaica and southward to Point Malaspina, on the Argentine coast, where it was dredged in 51 fathoms.

This little species is quite distinct from any of the others and wants the right anterior cardinal tooth. The radial ribs are strong and crossed by slender, sparse threads, which become lamellose on either side of the beaks. It may eventually be shown to be better placed in one of the groups included in Phacoides. ${ }^{1}$

${ }^{1}$ It is figured in the Porto Rico Report, pl. vI, fig. 9. 
The West American species are as follows:

CODAKIA COLPOICA Dall, igor.

Gulf of California.

This is Lucina tigerina Carpenter, but not of Linnæus; L. punctata of various authors, but not of Linnæus. The true tigerina Linnæus (L. exasperata Reeve) is Indo-Pacific, and so is L. punctata. Both of them have a sculpture very distinct from that of the Gulf species, and both have erroneously been reported from Panama, and the latter from the Galapagos by Wimmer.

\section{CODAKIA (JAGONIA) MEXICANA Dall, rgor.}

Gulf of California to Panama and Guacomayo.

This species is much like $C$. orbiculata Montagu, but has a quite different lunule. It is the Lucina pectinata Carpenter, 1857, but not of Gmelin, 1792, or C. B. Adams, 1847; L. fibula Reeve, ex parte (fig. 33 only), 1850; L. bella Carpenter, 1864, not of Conrad, 1837.

\section{CODAKIA (JAGONIA) GALAPAGANA Dall, Igor.}

Galapagos Islands, Chatham, Hood, and Indefatigable.

This form is easily distinguished from C. mexicana, which has entire ribs, by its coarser, somewhat annulated, and distally fasciculated radial ribs. It does not appear to pass south of the Galapagos Islands.

CODAKIA (JAGONIA) CHIQUiTA Dall, igor.

Off Lower California at station 2830, dredged by the U. S. Fish Commission in 66 fathoms, sand.

This is perhaps the smallest species of Jagonia in west American waters; with fine concentric and sparse obscure radial sculpture, and suborbicular outline.

Note.-A Lucina distinguenda is enumerated by Fischer from Panama, ${ }^{1}$ but without any author's name, and I am unable to discover any description or other reference to it in the literature which would enable me to determine what shell was intended. It is true, Fischer refers to it as the Pacific analogue of $L$. tigerina Linnæus, but as both tigerina and punctata have been reported from Panama, it is possible that there are more than one species of large Codakia native to that locality; and the one referred to by Fischer may prove, if identified, distinct from the Gulf species which I have named $C$. colpoica.

\section{Genus LUCINA (Bruguière) Lamarck.}

This is Lucina Bruguière, 1797 (not 1792, as often stated), in part; Lucina Lamarck, 1799; Anodontia Link, 1807; and Loripes of many

\footnotetext{
${ }^{1}$ Manuel, p. 160, 1881.
}

Proc. N. M. vol. xxiii- 51 
authors, but not of Cuvier, 1817, after Poli, 1791. Type, Lucina edentula Linnæus.

Shell inflated, thin, concentrically striated, anterior and posterior dorsal areas obsolete; lunule deep and narrow, no visible escutcheon; ligament and resilium deeply inset but not occluded; margins entire, anterior adductor scar long, hinge wholly edentulous, shell usually large.

The following subgenus may be admitted:

Loripinus Monterosato, 1883. Type, Lucina fragilis Philippi (=L. edentula Brocchi, not Linnæus), Mediterranean.

Shell small, with the ligament obsolete and the resilium wholly internal; the anterior adductor scar short and wide, otherwise like Lucina.

The following are the American species:

\section{LUCINA CHRYSOSTOMA (Meuschen) Philippi, 1847.}

Bermuda, South Florida, the West Indies, and northern coast of South America, in moderate depths of water.

This is Tellina crysostoma Meuschen, 1787, and Venus edentula Chemnitz, 1784; Anodontia alba Link, 1807; Lucina chrysostoma of Philippi, 1847, and Mörch, 1853.

It is the Lucina edentula of Reeve, 1850, and many other writers, but Hanley has shown that the Linnæan edentula (1758) was probably that named by Reeve L. ovum, an oriental form described by Forskal under the specific name of globosa (1776), and with which, according to von Martens (1880), L. pila Reeve is synonymous.

LUCINA PHILIPPIANA Reeve, 1850.

Cape Hatteras, North Carolina; Bermuda, and southward through the West Indies; Japan?.

This is the L. edentula Philippi, 1847, not Linnæus, 1758, and the L. schrammi Crosse, 1876. It varies sufficiently in its outline and convexity to suggest, in the absence of a series, that the student is dealing with more than one species.

A young valve of this species in defective condition may be the shell identified by Smith in the Challenger bivalves from near Bermuda as Lucina barbata of Reeve, an identification Mr. Smith regards as doubtful.

\section{LUCINA EDENTULOIDES Verrill, 1870.}

Magdalena Bay, Lower California, and in the Gulf of California.

It is Loripes edentuloides Verrill, 1870, and possibly was the shell intended by Carpenter when he cited a Lucina capax from Panama, to which I have not been able to find any other reference in the literature. This species is very similar to the West Indian form, but differs by its 
more central umbones, while the very similar Lucina bialata Pilsbry, of Japan, carries the process of centralizing the beaks almost to completion.

LUCINA PHENAX Dall and Simpson, rgor.

Mayaguez and San Juan harbors, Porto Rico, in 5 to 30 fathoms.

Small, delicate, sparsely concentrically threaded, with grayish periostracum, translucent white shell, the aspect of Loripinus, but the external ligament of Lucina. This species is described in the report on Porto Rico mollusks, prepared for the U. S. Fish Commission.

\section{Genus LORIPES Cuvier.}

Shell suborbicular with feeble sculpture, a narrow elongate lunule, posterior dorsal area obscure or absent; ligament obsolete, resilium separated from it, deeply immersed, wholly internal; hinge with the posterior laterals and right anterior cardinal absent, the anterior laterals often obsolete; margins entire, anterior adductor scar long and narrow.

Type, Amphidesma lucinalis Lamarck= Tellina lactea of Poli and others, but not of Linnæus, Lucina leucoma Turton, L. amphidesmoides and lacteoides Deshayes, and L. elata Locard. Habitat, Mediterranean.

The genus is Loripes Cuvier, 1817, not Schweigger, 1820; Thyatira Gray, 1847, not of Hübner, 1816; Ligula Menke, 1830, not of Montagu, 1803; Lucinida d'Orbigny, 1846, and Lucinidea Barrois (in Zittel), 1887.

The American species are:

? LORIPES CLAUSUS Philippi, 1848.

Belize, British Honduras, Rev. W. A. Stanton.

This species is solid, compressed, sharply concentrically, and minutely radially, striated; with a small but very distinct anterior dorsal area, deep short lunule, and well-developed anterior lateral tooth.

Lucina sulcata Reeve, May, 1850, is externally very similar, from the figure, but Reeve gives no data as to the hinge characters. L. clausus is figured by Philippi, 1850. Only one dead valve was received from . the collector.

\section{LORIPES CRYPTELLUS d'Orbigny, I846.}

Pernambuco, Brazil.

This species has a large dorsal anterior area, the hinge has the laterals obsolete as in L. lucinalis Lamarck, and the surface concentrically striate. As figured by d'Orbigny, the valves are markedly unequal, but this may have been an individual abnormality. It is much more inflated than L. clausus.

This species is called Lucina and Lucinida cryptella by d'Orbigny 
in his text, but on the Plate Lxxxiv of the atlas, where it is figured, the name is Lucina brasitiana d'Orbigny. It is not the Lucina brasitiensis of Philippi, 1848.

The name Lmipes has been very generally applied to the large, globose edentulous shells which are properly known as typical Lucina, but these have not an internal resilium. Loripes lens of Verrill and Smith, 1880, and L. compressa Dall, 1881, should be placed in the genus Myrtcea, as they also are destitute of the internal resilium which is the chief characteristic of the genus Loripes.

Genus MYRT $\nRightarrow$ A Turton, 1822.

This is Cyrachar Leach, 1852, and Ortygia (sp.) Brown, 1827. Type, Venus spinifera Montagu, 1803. Northern Europe.

Shell ovate or subrectangular, not inflated, the dorsal areas obsolete, sculpture chiefly concentric; lunule and escutcheon long and narrow; ligament and resilium deep-seated, but not internal, anterior adductor scar rather short; hinge with the right anterior cardinal normally absent and the left laterals frequently obsolete.

Two sections are discriminable:

Myrtæa s. s. Shell of moderate size, with purely concentric sculpture.

Eulopia Dall, 1901. Shell small, with radial vermicular sculpture between stronger concentric lamellæ. Type, Lucina sagrinata Dall, 1886.

This group appears in the Oligocene of Bowden, Jamaica.

The American species are as follows:

MYRT EA LENS Verrill and Smith, I88o.

From Cape Cod, Massachusetts, south to the Antilles and Rio de Janeiro, Brazil, in 50 to 464 fathoms, bottom temperatures ranging from $41.5^{\circ}$ to $46.5^{\circ} \mathrm{F}$.

This is Loripes lens of Verrill and Smith, 1880, but not Lucina lens of Roemer (Nordd. Kreidegeb.), 1841, nor Lucina lens of H. C. Lea (Virginia miocene) 1845.

MYRT ÆA COMPRESSA Dall, I88I.

Cuba and Sombrero, West Indies, in 72 to 424 fathoms.

This is Loripes compressa Dall, 1881, and may prove to be an extremely transverse and compressed variety of $M$. lens Verrill and Smith.

MYRT ÆA PRISTIPHORA Dall and Simpson, Igor.

Porto Rico, Santa Lucia, Barbados, and Grenada, in 30 to 300 fathoms.

Described and figured in the Porto Rico report of the U. S. Fish Commission. 


\section{MYRT ÆA (EULOPIA) SAGRINATA Dall, I886.}

Florida Keys and westward to Yucatan Strait, in 85 to 300 fathoms. A peculiar small shell with which Lucina fabula Reeve is naturally associated. It was described as Lucina sagrinata. ${ }^{1}$

Note.-The type of this genus is the Venus spinifera Montagu, 1803; + Myrtaca spinifera Turton, 1822; Lucina hiatelloides (Basterot) Philippi, 1836; and Lucina spinosa Philippi, 1844.

No species of this genus are yet reported from the Pacific coast.

\section{Genus PHACOIDES Blainville.}

This is Phacoides Blainville, 1825; Lucina Lamarck, 1801 (but not Lamarck, 1799); Triodonta (sp.) Gray, 1851 (not of Schumacher, 1817); Here Gabb, 1866; Linga de Gregorio, 1885; Cavilucina and Dentilucina Fischer, 1887.

This comprises most of the species included by many authors in Lucina, in a broad sense, but not the original Lucina of Lamarck, which has very generally been called Loripes erroneously.

Owing to the very numerous modifications of characters shown in this group, it becomes necessary, for clearness, to divide it into a rather large number of subdivisions, both subgenera and sections.

Subgenus Phacoides Blainville, s. s. Type Tellina pectinata Gmelin (+ Lucina jamaicensis Lamarck).

Shell lentiform, with strong dorsal areas and chiefly concentric sculpture, the cardinal teeth obsolete in the adult, but the laterals well developed.

This is Dentilucina Fischer.

Subgenus Here Gabb. Type, Lucina richthofeni Gabb.

Shell solid, globose, with developed dorsal areas and conspicuous concentric sculpture, the lunule often deeply impressed and the right anterior cardinal effaced, the other teeth well developed.

This is Lucina Schumacher, 1817, not Lamarck, 1799, + Linga de Gregorio, 1885. It may be divided into sections, the typical group, as above, and:

Section Pleurolucina Dall, 1901. Type, Lucina leucocyma Dall, 1886.

Shell with a small number of large radial ribs in addition to the concentric sculpture.

Section Cavilucina Fischer, 1887. Type, Lucina sulcata Lamarck.

Shell small, compressed, concentrically striate, the areas and teeth often obsolete, the lunule small and often deep.

Subgenus Lucinisca Dall, 1901. Type, Lucina nassula Conrad.

Shell lentiform, white, with well-marked dorsal areas, the sculpture reticulate and muricate, the right anterior cardinal obsolete.

${ }^{1}$ It is figured in the Proc. U. S. Nat. Mus., XII, 1889, p. 263, pl. xIv, fig. 11. 
This is a well-marked group, belonging in the warmer seas and having a very elegant type of sculpture.

Subgenus Miltha H. and A. Adams. This is Miltha H. and A. Adams, 1857, and Milthea Meek, 1876. The type is Lucina childreni Gray, 1825 , as Tellina.

This group is solid, compressed, concentrically striate, with a conspicuous periostracum, narrow impressed lunule, inconspicuous dorsal areas, deeply inset but not internal ligament and resilium and entire margins. It is divisible into two sections:

Miltha s. s. Hinge with two clean-cut cardinal teeth in each valve, the inner pair bifid, the laterals absent or obsolete.

Pseudomiltha Fischer, 1885. Type, L. gigantea Deshayes, Eocene of Paris.

Shell much like Miltha, but with the hinge teeth wholly obsolete.

This type goes back to the beginnings of the Tertiary and includes some of the largest lucinoid forms known; one, the Lucina megameris Dall, of the Jamaican Oligocene, reaches a length of some 10 inches.

Subgenus Lucinoma Dall, 1901. Type, Lucina filosa Stimpson.

Shell usually large, lentiform, white, with a conspicuous periostracum, concentrically lamellose or striated; the cardinal teeth developed, the inner pair usually bifid; the laterals obsolete or absent, the inner margins entire.

This is a well-marked group with extensive geographical and geological distribution, inhabiting preferably cold waters and frequently abyssal depths.

Subgenus Callucina Dall, 1901. Type, Lucina radians Conrad.

Shell Dosinoid, concentrically filose, sometimes with feeble radial sculpture; the dorsal areas obsolete; the lunule small, comprised chiefly in one valve and fitting into a recess in the opposite valve; hinge with one cardinal in each valve, the other teeth feeble or absent; inner margins crenulate.

The $L$. concentrica Reeve is also a member of this group, which comprises the typical section, as above; and

Section Epilucina Dall, 1901. Type, Lucina Californica Conrad.

Shell veneriform, convex, all the hinge teeth developed, inner margins entire; otherwise like Callucina.

Subgenus Parvilucina Dall, 1901.

Shell small, plump, often inequilateral; sculpture more or less reticulate but not muricate, teeth small, but all usually present.

Section Parvilucina s. s. Type, Lucina tenuisculpta Carpenter.

Dorsal areas obscure or obsolete, sculpture feeble.

Section Bellucina Dall, 1901. Type, Parvilucina eucosmia Dall, 1901 (= Lucina pisum Reeve, 1850, not Sowerby, 1837, nor d'Orbigny, 1841, nor Philippi, 1850).

Dorsal areas and sculpture strong. 
? Subgenus Prolucina Dall, 1896. Type, Lucina prisca ${ }^{1}$ Hisinger, Silurian.

Shell compressed, arcuate, almost rostrate, the anterior portion larger, the anterior adductor scars high, large, Lucinoid; the posterior narrow, elongate. Teeth unknown.

This group appears to be genuinely Lucinoid, though Paracyclas Hall, generally referred to the Lucinacea, should probably be excluded from it, having no really Lucinoid features.

\section{EAST AMERICAN SPECIES.}

\section{PHACOIDES PECTINATUS Gmelin, I792.}

St. Augustine, Florida, to the West Indies and southward to Montevideo, Uruguay, in shallow water.

This is Tellina pectinata Gmelin, 1792, and Wood, 1815; Tellina jamaicensis Spengler, 1798; Tellina scabra (Chemnitz) Wood, 1815; Lucina jamaicensis Lamarck, 1818; Lucina scabra Gray, 1825; Lucina (Phacoides) jamaicensis Blainville, 1825; Lucina funiculata Reeve, 1850, but not Lucina pectinata C. B. Adams, 1852, nor Carpenter, 1857.

PHACOIDES (HERE) PENSYLVANICUS Linnæus, $175^{8}$.

Cape Hatteras, North Carolina, south to and throughout the West Indies and the continental shores adjacent, in shallow water, onefourth to 6 fathoms.

This is Venus pensylvanica Linnæus, 1758; Lucina pennsylvanica Reeve, 1850; Lucina grandinata Reeve, 1850, and Lucina speciosa Reeve, 1850, but not L. speciosa Rogers, 1836.

This well-known species is a very beautiful object when its periostracum is perfect, but the differences in the latter upon which Reeve founded one of his species are not constant in individuals from the same locality. The oriental Lucina virgo Reeve, which Tryon unites with this species, appears to me to be distinct, but I have some suspicion that the L. obliqua Philippi, 1850 (April, not of Reeve, June, $1850)$, may have been founded on a young shell of this species.

PHACOIDES (HERE) ADANSONII d'Orbigny, r839.

Senegal, Canaries; St. Thomas, and other localities in the Windward Islands of the West Indies.

This is the Lucina columbella of authors, but not of Lamarck, whose type is a fossil of the French Miocene. It seems rare in the West Indies. It is not the Lucina adansonii Reeve $(1850)=$ senegalensis Reeve, in errata.

${ }^{1}$ See Zittel, Textb. Pal. I, 1896, p. 408. 


\section{PHACOIDES (HERE) AURANTIUS Deshayes, 1830.}

St. Thomas, Santa Cruz, Guadeloupe, the Virgin Islands, and other localities in the Lesser Antilles, in one-fourth to 1 fathom water, sandy
bottom.

This species is distinguishable from $P$. adanson $\ddot{i}$ by other characters than its salmon-colored margins. It is the Lucina aurantia of Deshayes and has also been reported from the Azores.

\section{PHACOIDES (HERE) SOMBRERENSIS Dall, r886.}

Northern part of the Gulf of Mexico south to Sombrero Island, West Indies, in 60 to 84 fathoms.

This resembles $P$. adanson $\ddot{i}$ in miniature. ${ }^{1}$

\section{PHACOIDES (PLEUROLUCINA) LEUCOCYMA Dall, I886.}

Cape Hatteras, North Carolina, and south to Cuba, in 49 to 683 fathoms.

This is immediately recognizable by its few broad ribs and small white shell, which is figured with the preceding. ${ }^{2}$

PHACOIDES (CAVILUCINA) TRISULCATUS Conrad, I84I.

Cape Hatteras, North Carolina, south to Cabo San Roque, Brazil, in 10 to 20 fathoms.

Notable for its obliquity and its two or three strongly marked resting stages, from which the name is derived. The original Lucina trisulcata Conrad, is a miocene fossil. The recent shell usually called by this name is often very similar to the fossil, but there is a larger, flatter, less coarsely sculptured form in the West Indies which has much less emphatic resting stages, and, if not distinct, is at least a recognizable variety, which may be called blandus. ${ }^{3}$ It is intermediate between the typical $P$. trisulcatus and the Pacific coast P. lamprus. It varies from white, through yellow, to orange color.

\section{PHACOIDES (LUCINISCA) NASSULA Conrad, 1846.}

Cape Hatteras, North Carolina, south to Cuba and west to Mobile Bay, in 7 to 200 fathoms.

This is Lucina lintea Conrad, 1866, and Lucina nassula Conrad, 1846. It is not the shell intended by Guppy, under the name of "nasuta Conrad," which is a Jagonia, but Conrad has not described any Lucina nasuta.

\footnotetext{
${ }^{1}$ See Proc. U. S. Nat. Mus. XII, 1889, p. 263, pl. XIV, fig. 13.

${ }^{2}$ Idem, 1889, pl. xrv, figs. 6, 7.

${ }^{3}$ See Report on Porto Rico shells, p. 493, 1901, pl. vi, fig. 13.
} 
PHACOIDES (LUCINISCA) MURICATUS Spengler, I798.

Florida Keys and West Indies, with adjacent coast, in 6 to 12 fathoms. (Pacific coast??)

This is Tellina muricata Spengler, 1798; T. imbricata Chemnitz (1799?); Lucina scabra Lamarck, 1818, but not Tellina (=Lucina) scabra of Chemnitz and Dillwyn, 1817; and Lucina scobinata Recluz, 1852. It is very easily recognized by its spinose radial sculpture prevailing over the concentric portion, while in the preceding species the reticulation is nearly uniform and the spinosities not prominent.

PHACOIDES (PSEUDOMILTHA) FLORIDANUS Conrad, I833.

West coast of Florida from Charlotte Harbor to Cedar Keys, and westward to Corpus Christi, Texas.

Surface with rather rude concentric growth stages and a pale papery periostracum; the shell usually flat and rather heavy. It was describejd as a Lucina and referred by Tryon (1872) to Loripes.

PHACOIDES (LUCINOMA) FILOSUS Stimpson, r851.

Casco Bay, Maine, south to Cape Florida, in 16 to 528 fathoms.

This is the Lucina radula Gould, 1841, but not of Montagu, 1803; and the L. contracta De Kay, 1843, not of Say, 1824. It has been united, erroneously, with the Phacoides borealis Linnæus, by several authors. It is a cold-water shell, and is found in increasingly greater depths as it passes southward.

PHACOIDES (LUCINOMA) BLAKEANUS Bush, 1893.

Massachusetts Bay to Cape Fear, North Carolina, in 18 to 464 fathoms.

Very close to the preceding species, but more quadrate, more sparsely lamellose, and with a relatively shorter anterior adductor scar, and shallower sulcus for ligament and lunule.

? PHACOIDES (LUCINOMA) BOREALIS Linnæus, I766.

Iceland. European seas. Northeast America?

This is the Venus borealis of Linnæus in 1766, but not of Gmelin, 1792; the Venus spuria of Gmelin, 1792; Tellina radula Míntagu, 1803; Lucina alba Turton, 1822, and Thiatira spuria Gray, 1847. This species has been reported from the east and west coasts of America by Carpenter, Cooper, and others, but the nearest authentic record is Iceland, on the authority of Steenstrup. The others are doubtless due to confusion with related but not conspicuously similar species.

PHACOIDES (CALLUCINA) RADIANS Conrad, I84I.

Cape Lookout, North Carolina, and south to Florida, Bermuda, and Porto Rico, in 5 to 85 fathoms, living, dead valves in 287 fathoms. 
This is Lucina radians Conrad, 1841, and Lucina radiata of Conrad in his Medial Tertiary, 1845, but not Lucina radians Deshayes (in Melleville) 1843, which is a Felaniella.

\section{PHACOIDES (CALLUCINA) BERMUDENSIS Dall, igor.}

Bermuda, Hartt.

This appears to be Lucina lenticula Reeve, August, 1850, not of Gould, June, 1850. I have therefore substituted a new name for the preoccupied term. The specimens which agree very well with Reeve's figure ${ }^{1}$ were found incrusted in the limy sand of the beach and no living ones have come to my notice. It is not the species catalogued by me in 1889 as L. lenticula. ${ }^{2}$

PHACOIDES (PARVILUCINA) CRENELLA Dall, Igor.

Cape Henry, Virginia, south to Cuba, in 2 to 124 fathoms.

This is Lucina crenulata Dall, ${ }^{2}$ but not of Searles Wood, 1840-1853, or Conrad (1834), 1840.

\section{PHACOIDES (?) LENTICULUS Gould, $185^{\circ}$.}

Rio Janeiro (?) United States exploring expedition, under Wilkes.

This is Lucina lenticula Gould, 1850 (not of Reeve). A dubious species of which the type is lost, the locality uncertain, and which is erroneously called Cyclas on Gould's plate.

\section{PHACOIDES (BELLUCINA) AMIANTUS Dall, rgor.}

Cape Lookout, North Carolina, south to the West Indies and to San Sebastian, Brazil, in 2 to 640 fathoms, living.

This is the Lucina costata, ${ }^{2}$ of Dall, 1889, but not of d'Orbigny, 1846, or of Tuomey and Holmes, 1856. A very elegant little species, the analogue of Lucina cancellaris Philippi, of the Pacific coast. Living specimens have been found on the reefs among the Florida Keys by Hemphill and also dredged in 640 fathoms, Yucatan Strait, by the U. S. Coast Survey Steamer Blake, a very remarkable bathymetrical range.

WEST AMERICAN SPECIES.

PHACOIDES (HERE) RICHTHOFENI Gabb, 1866.

Catalina Island to Gulf of California, in 16 to 66 fathoms.

The analogue of the Atlantic $P$. adansonii d'Orbigny, but with a more capacious lunule. This feature, however, differs considerably at different ages of the same individual, and the young show but little

${ }^{1}$ Conch, Icon., XI, fig. 67.

${ }^{2}$ See Bull. U. S. Nat. Mus., No. 37, 1889, p. 50. 
excavation. The young is Lucina excavata Carpenter, 1857, not of d'Orbigny, 1851, but not the excavata of most west coast collections.

\section{PHACOIDES (HERE) MAZATLANICUS Carpenter, I857.}

Mazatlan.

Carpenter's specimens are so small that it is difficult to be certain about them, but they appear to be a distinct species, allied to the Atlantic P. sombrerensis. They are distinguished from young approximatus by their dense concentric lamellation.

\section{PHACOIDES (CAVILUCINA'LAMPRUS Dall, Igor.}

Gulf of California.

This varies from white to orange color, is concentrically filose, and often has the teeth quite distinct. It is Lucina excavata of most of the Pacific coast collections, but not of Carpenter, 1857, or of d'Orbigny, 1851.

PHACOIDES (CAVILUCINA) LINGUALIS Carpenter, I864.

? Monterey, California. Gulf of California to Acapulco, Mexico.

The Pacific analogue of the Atlantic P. trisulcatus Conrad. Valves were collected at Monterey by Gabb, but they were probably adventitious, as no other collector has found the species north of the Gulf.

PHACOIDES (CAVILUCINA) PROLONGATUS Carpenter, 1857.

Cape St. Lucas.

A miniature of the preceding, with exaggerated obliquity. It appears to be rare, and I have seen only worn valves.

\section{PHACOIDES (PLEUROLUCINA) UNDATUS Carpenter, 1865.}

Gulf of California.

This is Lucina undata Carpenter, 1865, but not of Lamarck, 1818. Since Lamarck's species had been transferred to Lucinopsis (= Mysia) before the publication of Carpenter's name, the latter need not be rejected.

PHACOIDES (LUCINISCA) FENESTRATUS Hinds, I844.

Lower California to Panama (and Tumbez, Peru?), in 10 to 30 fathoms.

The finest and largest species of the subgenus, in occasional individuals of which a dwarf anterior right cardinal is perceptible. A young valve, probably of this species, was referred to Lucina muricata by Carpenter in the Mazatlan Catalogue, but the latter is not known from the Pacific Coast. Lucina ochracea Reeve, 1850, should be compared with this species. 


\section{PHACOIDES (LUCINISCA) NUTTALLII Conrad, I837.}

Santa Barbara, California, to the Gulf of California, in 16 to 30 fathoms.

The Pacific analogue of $P$. nassula Conrad of the Gulf of Mexico, but a larger and finer shell. A variety, centrifugus Dall, has the concentric sculpture near the beaks sparser, more elevated and fringed with flat spinules, usually worn off; it was dredged in the Gulf in 26 fathoms. Owing to the manner in which the muricate species have been confused with one another, it is difficult to disentangle their distribution from the literature; but I have seen no authentic specimens of this species from south of the Gulf of California.

\section{?? PHACOIDES (LUCINISCA) MURICATA Spengler, I798.}

\section{"Tumbez, Peru," Reeve; "? Mazatlan" Carpenter.}

The synonymy of this species will be found in the east coast list. I have never seen an authentically west coast specimen of this shell. It is not found in any of the faunal publications on this coast except that of Carpenter, and there, only with doubt, is identified from a minute fragment, less than a tenth of an inch long. Reeve's localities are notoriously unreliable. I consider that the presence of this species on the Pacific coast is yet to be demonstrated, but do not feel justified in omitting all reference to it here.

PHACOIDES (MILTHA) CHILDRENI Gray, 1825.

Gulf of California, Cape St. Lucas, Mazatlan.

This large flat species is unmistakable; the locality, Brazil, given in the Conchologia Iconica, is erroneous. The type specimen was described as inequivalve, but the specimens I have seen appear to be entirely equivalve. It was first described as a Tellina.

\section{PHACOIDES (PSEUDOMILTHA) TELLINOIDES Reeve, I850.}

Magdalena Bay, west coast of Lower California, south to Guayaquil, in 11 fathoms.

Very like the M. floridana Conrad, but more elegant, and with a bright yellow periostracum. It seems to have been at first confused by Carpenter with Felaniella sericata, owing to the fact that Reeve's figure is not very characteristic. It was described as a Lucina.

\section{PHACOIDES (LUCINOMA) HEROICUS Dall, Igor.}

Off West Mexico, in 1,005 fathoms, in latitude $27^{\circ} 24^{\prime}$ N., Gulf of California.

One of the finest species of this interesting and characteristic group, much larger than aquizonatus Stearns, and with a rounder outline. 
PHACOIDES (LUCINOMA) ANNULATUS Reeve, r850.

Sitka, Alaska, and south to San Pedro, California, in 8 to 135 fathoms.

This is the Lucina borealis of Cooper, Carpenter, and Gabb, but not of Linnæus; Lucina filosa Dall, 1870, not Stimpson, 1851; Lucina acutilineata of Gabb and other Californian authors, but not of Conrad, 1849; acutilirata "Conrad" of Cooper, 1864, in Carpenter, meaning acutilineata. Reeve's figure of his annulata, doubtfully referred to California, so exactly represents a young specimen of this species which has bleached or lost its yellowish periostracum, that I have little hesitation in referring it to our shell.

PHACOIDES (LUCINOMA) ÆQUIZONATUS Stearns, I89o.

(Plate XLI, figs. 2, 3.)

Santa Barbara channel, in 276 fathoms; a very distinct subquadrate species.

PHACOIDES (LUCINOMA) LAMELlatus E. A. Smith, r88I.

West coast of Patagonia, in 10 to 369 fathoms, also in St. Andrews Bay.

A well marked species from the southern extreme of South America, originally described as a Diplodonta.

\section{PHACOIDES (EPILUCINA) CALIFORNICUS Conrad, 1837}

Crescent City, California, south to San Diego, in 3 to 15 fathoms; Acapulco?

This is the Lucina californica of Conrad, and the young were named $L$. artemidis by Carpenter in 1856. A species unique in its characters among recent shells, but with an analogue in the Tertiaries of the southeastern States.

PHACOIDES (PARVILUCINA) TENUISCULPTUS Carpenter, I865.

Nunivak Island, Bering Sea, and southward to Catalina Island, California, in 8 to 135 fathoms.

A species of which the metropolis is in the cold waters of the northern coast.

PHACOIDES (PARVILUCINA) APPROXIMATUS Dall, Igor.

Catalina Island, California, and south to Panama, in 5 to 40 fathoms.

Closely related to the last species, but smaller, more delicate, without the anterior right cardinal tooth which is developed in the northern shell, and most abundant in the Gulf of California. 


\section{PHACOIDES (BELLUCINA) CANCELLARIS Philippi, r846.}

Cerros Island, west of Lower California, and south to the Gulf and to Panama, in 5 to 30 fathoms.

An elegantly sculptured species, with analogues on the Atlantic coast and in the China seas.

Notes.-The Lucina cristata of Recluz (not of Smith, 1885), is a Tellidora, near T. Burneti Broderip and Sowerby, but found on the Atlantic coast. Lucina pulchella C. B. Adams, 1845, not Grzybowski, 1899, is a Strigilla. Lucina corrugata Deshayes, 1843, is credited by him to California, but really belongs to the Indo-Pacific fauna, and has been collected at Singapore. It is Lucina philippinarum Hanley, 1850. Lucina sulcata Reeve, 1850 , which has some external similarity to Loripes clausus Philippi, is regarded by Mr. E. A. Smith as identical with $L$. argentea Reeve, from the Moluccas, and appears to have the characters of Phacoides. Lucina caribaa d'Orbigny, of Beau's catalogue of the shells of Guadeloupe, is apparently a nomen nudum, as I have not been able to find any description of it in the literature.

A Lucina oerstedti of Mörch is listed from the West Indies in the Poulsen catalogue, but it is probably a manuscript name, and no shell so labeled now appears in the Poulsen collection at Christiania, according to Dr. Collett.

\section{Genus DIVARICELLA von Martens, 1880.}

This is Cyclas of Mörch, 1853, not of Lamarck, 1799; Egraca (sp.) of Leach, 1852; Lucinella Monterosato, 1883; Loripes and Lucina (sp.) of various authors. Type, D. angulifera von Martens = Lucina ornata Reeve, 1850, not of C. B. Adams, 1852, Mauritius.

This genus is divisible as follows:

Section Divaricella s. s.

Valves suborbicular, convex, subequilateral, with inconspicuous beaks, no dorsal areas, two cardinal teeth in each valve, the laterals variable, the posterior distant, usually obsolete; the anterior feeble, adjacent; ligament and resilium set in a groove, but not internal, the excavated striæ forming an angle on a line radial from the beaks. Type, D. ornata Reeve.

Section Pompholigina Dall.

Valves extremely tumid, the umbones subspiral, the teeth cyclodont, anterior and posterior dorsal areas indicated. Type, Lucina gibba Gray, W. Africa.

Section Bourdotia Dall.

Valves very inequilateral, subquadrate, the anterior end produced, the anterior dorsal margin concavely arcuate; a single minute cardinal in each valve; laterals obsolete; the excavated external sulci arcuate, not angulate. Type, Lucina Bourdoti Cossmann, 1882, Parisian Eocene. 
Subgenus Lucinella Monterosato, 1883.

Shell like Divaricella, but the ligament obsolete and the resilium wholly internal, as in Semele. Type, Lucina commutata Philippi, $1836,=$ Tellina divaricata Linnæus, 1758; Mediterranean and western Europe.

LIST OF THE AMERICAN SPECIES.

DIVARICELLA QUADRISULCATA d'Orbigny, I846.

Nahant Beach, near Boston, Massachusetts, and southward to the West Indies, Rio de Janeiro and Santa Caterina, Brazil, in from 10 to 50 fathoms.

This is (from types) Lucina strigilla Stimpson, 1851, and L. divaricata of Gould, 1841, and other early writers. It is also the Lucina americana of C. B. Adams in 1852; the Cyclas dentata of Verrill, 1873, and the Lucina commutata Arango, 1878, not of Philippi, 1836. A variety transversa Dall, 1901, with the valves disproportionately elongate in the direction of the hinge line, has been dredged in 22 fathoms off Cape Lookout, North Carolina, by the U. S. Fish Commission.

This species is distinguishable from the next by its longer, small and narrow, somewhat sinuous lunule and fine crenulation of the interior margins. The adult has no denticulations of the outer margin due to the external sculpture.

DIVARICELLA DENTATA Wood, I8I5.

Cape Hatteras, North Carolina, south to the West Indies (and, according to d'Orbigny, to Brazil), in 10 to 60 fathoms.

It is the Lucina divaricata of many of the early writers, but not of Linnæus; but not the Lucina dentata of Defrance, 1823; the L. serrata of d'Orbigny, 1846; the L. chemnitsii of Philippi, 1848, and the L. pilula C. B. Adams, 1852 (young shells), are synonymous.

It may be known by its very small, deep, cordate lunule at any age, and in the adult it differs from $D$. quadrisulcata by its greater size and the denticulation of the lateral and dorsal margins by the external sculpture. The large specimens have a tendency to obsolescence noticeable in the teeth, and the laterals are often quite imperceptible.

DIVARICELLA EBURNEA Reeve, I850.

Cape St. Lucas, Lower California, and southward to Panama.

It is the Lucina eburnea of Reeve, 1850, but not of Deshayes, 1835 . It may be distinguished from the Antillean D. quadrisulcata d'Orbigny by its shorter, wider, and cordate lunule, and by the well-developed lateral teeth, which are well marked and distinct at all ages. The sculpture is also usually more arcuate.

DIVARICELLA PERPARVULA Dall, Igor.

Cape St. Lucas, Lower California, south to Guacomayo.

This is the Lucina pisum of Philippi in April, 1850, but not of 
Reeve (= seminula Gould, 1861, but not of Deshayes, 1858) in November, 1850; nor the L. pisum Sowerby, 1837, nor the L. pisum d'Orbigny of 1841 .

It is a small, globular species, with rather sparse external sculpture, more tumid than the young of $D$. eburnea. The specific name has been used so many times for different species of Lucina, senso lato, that it seems best to substitute a new one to avoid confusion. It has been found, adventitiously, at Monterey, California, by Gabb, with other exotic species.

Note.-The Lucina digitalis Krebs, 1864, not Lamarck, 1818, appears to be the Strigilla pisiformis of Linnæus. The Lucina pulchella C. B. Adams (Proc. Boston Soc. Nat. Hist., II, p. 10, 1845, but not of Agassiz, 1845) was also founded on Strigilla pisiformis.

\section{? Family CORBID A.}

\section{Genus CORBIS Cuvier.}

This comprises Gafrarium (sp.) Bolten, 1798; Corbis Cuvier, 1817; Fimbria Megerle, 1811, but not of Bohadsch (Nudibranchiata) 1761; Idothea Schumacher, 1817, but not of Fabricius (crustacea) 1793. The type and sole recent species is Venus fimbriata Linnæus, 1758, + Fimbria magna Megerle, 1811, + Idothaca perforata Schumacher, 1817. It is a native of the China seas, from which several varieties have been described.

The generic name of Bolten, meaning a waffle iron, in allusion to the cancellate external sculpture, was applied to an assembly comprising one species subsequently made the type of Corbis; five species subsequently included in Circe Schumacher; and one peculiar Venus ( $V$. reticulata Linnæus) which will have to retain the name if it be retained at all. We arrive, by the method of elimination, at this result, which, fortunately, is more convenient than to throw out names so universally accepted as Corbis or Circe.

In the Yoldi Catalogue ${ }^{1}$ Mörch lists this species from the Antilles. In the Mazatlan Catalogue Carpenter ${ }^{2}$ describes a minute shell which he suspected to be the young of a species of this genus, but to which he prudently gave no specific name. Mörch's reference is certainly erroneous and no confirmation of Carpenter's suspicion has been received, though collections in the Gulf of California have continued to be made for nearly half a century. The genus is represented in our early Tertiaries, but does not appear to have survived into the Miocene. I see no reason for supposing that it forms a member of the recent fauna on either of our coasts.

\footnotetext{
${ }^{1}$ Volume II, 1853, p. 33.

${ }^{2} 1857$, p. 101.
} 


\section{Family CYRENELLID A.}

The shells of this group, with a Lucinoid animal and Diplodontalike shell, exhibit a hinge structure which is wholly distinct from any other of the Lucinacea. They are of brackish or fresh water situs and confined, as far as known, to the borders of the subtropical Atlantic and the Tertiaries of the southern United States.

Genus CYRENOIDA Joannis.

This is Cyrenoida Joannis, June, 1835, Cyrenella Deshayes, Feb., 1836, and Cyrenoides Sowerby, 1842. Type, C. dupontia Joannis, Senegal.

Shell thin, inflated, suborbicular, with a brownish or yellowish periostracum, concentrically feebly striated; adductor scars subequal, elongate-ovate, the anterior projecting very little into the area within the pallial line, internal margins not crenulate; hinge with a long external ligament enfolding a smaller resilium; right valve with two,

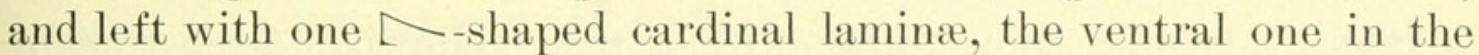
right valve shorter and more compressed, the "hooks" or shorter limbs of the laminæ tending to be sulcate or bifid. There are no laterals. The original type appears to have had a defective hinge, as the figure of this part of the shell given by Joannis is erroneous.

\section{CYRENOIDA AMERICANA Morelet, I85I.}

Cuba and Porto Rico, in the deltas of streams.

More transverse than the African species and with a more delicate hinge and less prominent umbones. ${ }^{1}$

\section{CYRENOIDA FLORIDANA Dall, 1896.}

Brunswick, Georgia, south to the Everglades of Forida, and in west Florida, north to Charlotte Harbor and vicinity, in brackish marshes.

Smaller and more delicate and less quadrate than the Porto Rico species.

A much larger species occurs in the Pliocene of the Caloosahatchie beds of Florida, and has been named (1896) C. caloosaënsis Dall. It reaches a length of $31 \mathrm{~mm}$.

\section{NOTES AND DESCRIPTIONS OF NEW SPECIES.}

THYASIRA BISECTA (Conrad).

(Plate XL, fig. 8; plate XLII, fig. 5.)

Figures are of a recent specimen with a length of $50 \mathrm{~mm}$., which was dredged southeast of Alaska Peninsula in 69 fathoms, mud, the bottom temperature being $44^{\circ} \mathrm{F}$. The younger specimens dredged at 
the same time show no essential differences except of size. Another specimen from 135 fathoms in Puget Sound measures $74 \mathrm{~mm}$. in extreme length and about $28 \mathrm{~mm}$. in diameter. I have seen some fossil specimens which attained even larger dimensions. The shell recalls Megaximus rostratus (Pecchioli) in almost every respect, but the distal ends of the nymphs do not project as strongly as in that species.

THYASIRA CONIA Dall and Simpson.

(Plate XLII, fig. 2.)

As this came to hand too late to be figured in the Porto Rico report, I give a figure of the species here from the largest specimen obtained in the vicinity of San Juan Harbor, in 310 fathoms, by the U. S. Fish Commission.

THYASIRA EXCAVATA, new species.

(Plate XXXIX, figs. 12, 15.)

Shell subovate, thin, white, with a pale yellowish periostracum; sculpture of concentric incremental lines, and in each valve three sharp and two or three obscure radial ridges. Beaks small, subacute, not prominent, distinctly prosogyrate; lunule and escutcheon well developed, elongate, rather narrow, and emphatically excavated, bounded by a well-marked carina, which in the case of the escutcheon is high, thin, and sharp, separated from another less acute radial keel by a wide, deep sulcus; on the disk near the middle are two other radials, evident but obscure, and another a short distance behind the lunular carina. The surface occasionally shows a faint dusting of microscopic granulation, which is usually abraded. Valves moderately convex, the interior polished, the hinge edentulous, the nymphs slender and delicate, the ligament narrow and more or less visible externally, the margin of the valve indented by the external ridges. Lon. 20.0 , lat. 17.5 , diam. $15.0 \mathrm{~mm}$.

Dredged by the U. S. Fish Commission in the Gulf of California, between San Marcos Island and Guaymas, in 1,005 fathoms; bottom temperature, $37^{\circ} .6 \mathrm{~F}$. Also off Tillamook, on the coast of Oregon, in 786 fathoms, mud; bottom temperature, $37.3 \mathrm{~F}$.

This species is markedly characterized by the deeply excavated and sharply bounded escutcheon and lunule, in which respect it is not closely approached by any other.

THYASIRA TOMEANA, new species.

(Plate XXXIX, fig. 3.)

Shell moderately convex, subovate, concentrically sculptured with incremental lines and covered by a pale straw-colored periostracum. Lunule small, ovate, lanceolate, moderately impressed; escutcheon 
long, very narrow, bordered externally by a sharply incised groove; behind this a rather shallow sulcus radiates from the beak, bounded behind by a rounded radial ridge; ligament thin, delicate, set in a narrow groove; margins reflecting the external sculpture, beaks narrow, prosogyrate, inconspicuous. Lon. 14.5, lat. 13.0, diam. $9 \mathrm{~mm}$.

Several valves came up with mud on the anchor from a depth of ten fathoms in the roadstead of Tomé, Chile.

THYASIRA MAGELLANICA, new species.

(Plate XLII, fig. 6.)

Shell small, white, subovate, moderately convex, with rather high and prominent beaks; external surface sculptured with faint incremental lines and shallow, ill-defined radial sulci; lunule small, moderately impressed, but without any well-defined bounding ridges; escutcheon narrow, obscure; just in front of it a shallow sulcus radiates from the beaks to the basal posterior margin; hinge edentulous, ligament feeble. Alt. 4.7, lat. 3.5 , diam. $3.0 \mathrm{~mm}$.

A single valve was obtained on the west coast of Patagonia in 194 fathoms, mud, the bottom temperature being $52^{\circ} \mathrm{F}$.

This species appears to differ from T. fuegiensis Dall by its more elevated form, smaller size, and especially by the position of the posterior radial sulcus, which, though feeble as in that species, is situated much closer to the posterior dorsal margin.

\section{AXINOPSIS SERICATUS (Carpenter).}

(Plate XL, fig. 2.)

I have figured a typical specimen of Carpenter's shell for comparison with the following form, and also because the former has never been figured. Both the West American species are more solid shells and have the cardinals much better developed than the A. orbiculatus Sars of the North Atlantic. The specimen figured is from Puget Sound, where it was dredged by Dr. Kennerly.

\section{AXINOPSIS VIRIDIS, new species.}

(Plate XL, fig. 1.)

Shell small, polished, suborbicular, when fresh covered with a glistening pale-green periostracum, some times exhibiting lighter and darker concentric zones; sculpture solely of fine concentric lines of growth; beaks low, inconspicuous; lunule slightly impressed, but without any bounding sulcus or ridge, small, sublanceolate; escutcheon hardly recognizable, very narrow, and inconspicuous. The part of the lunule belonging to the right valve is slightly larger than the other. The ligament is small and very delicate, but not wholly concealed. The 
subumbonal tooth of the right valve is prominent and strong, the inflected tooth-like process of the left valve is well developed. Margins of the valves smooth, interior polished, with some obscure radial striæ; muscular and pallial impressions normal. In the animal the hepatic glands project in an arborescent manner from each side of the comparatively insignificant bodymass, the gills are normal and rather small. Alt. of shell 6.0, lon. 6.2 , diam. $3.3 \mathrm{~mm}$. The specimen figured is from Iliuliuk, Alaska, in 19 fathoms, mud.

Ranges over the North Pacific region from Bering Strait to Northern Japan on the west and Catalina Island, California, on the south and east, in 5 to 167 fathoms, muddy or sandy bottom.

I have described this shell with some hesitation, as it may prove to be the normally rotund form of which $A$. sericata Carpenter is an oblique and ovate variety, but until this is shown it would seem as if the differences are worthy of systematic recognition. The Carpenterian type measures in alt. 4.5 , lon. 4.0 , and diam. $2.6 \mathrm{~mm}$; the beaks are higher and more recurved, the periostracum pale yellowish gray and papery.

DiPLODONTA (TORELli Jeffreys, var.?) ALEUTICA, new species.

(Plate XLII, fig. 3. )

Shell large, coarse, chalky, with a papery dehiscent periostracum, usually with the exterior more or less eroded; form somewhat longer than high, tumid, equivalve and nearly equilateral, the anterior end of the shell less rotund than the posterior; surface in the adult with rather irregular and marked concentric lines of growth; ligament external, set in a groove, with well-marked nymphs; teeth normal, slender, and delicate, in the adult more or less defective; beaks low and inconspicuous, slightly nearer the anterior end; interior chalky, the margins entire, the posterior muscular impression larger than the anterior. The young are proportionally more elongate and less tumid, with a smooth silky olivaceous periostracum. Lon. of adult, 26.5 , alt. 22.0 , diam. $14.0 \mathrm{~mm}$.; of young shell (figured), lon. 15, alt. 12, diam. $6 \mathrm{~mm}$. The figured specimen is from 10 fathoms, sandy mud, in Kyska Harbor, Aleutians; the type from 8 fathoms in the same body of water.

The species ranges from the Pribilof Islands to the Aleutian chain and eastward to the Shumagin Islands. It has not been found in the dredgings north of the Pribilof group.

The adult shell looks remarkably like the $D$. torelli Jeffreys, of the North Atlantic and Spitsbergen seas. Owing to their usual state of erosion it is difficult to compare adults, but the young of $D$. torelli has a coarsely wrinkled, yellowish periostracum and a rougher surface than that of aleutica. The ranges of the two are separated by an immense distance, but, whether due to analogous environment or congenetic origin, the adult shells are nearly indistinguishable. 
From D. orbella Gould this species is easily separable on account of the more rotund and inflated shell, the texture of the shell substance and the more adherent periostracum of the former.

CODAKIA COLPOICA, new species.

(Plate XLI, fig. 4.)

This shell resembles the $C$. orbicularis Linnæus, so much that it has long been confounded with it and the most appropriate description is comparative. The $C$. colpoica when compared with $C$. orbicularis of similar size is flatter, with the radical sulci more numerous and the interspatial ridges consequently more numerous, more slender, and more uniform. In orbicularis the posterior dorsal area is usually well marked by finer and different sculpture from that of the rest of the disk, and near the dorsal margin the sculpture is frequently subspinose or minutely prickly. In colpoica the sculpture of the dorsal part of the shell insensibly merges into that of the disk and if anything is rather smoother. There is also a slightly lurid tint in the exterior white of colpoica, while that of orbicularis is more purely immaculate and snowy. The most conspicuous character however is in the lunule. This in colpoica is rather long and narrow, in orbicularis, short, cordiform, and more deeply impressed. In both it is confined to the right valve. In orbicularis the hinge teeth are usually more prominent, stouter, and adjacent to each other than in the Gulf species.

The specimen figured is from the Gulf of California, and has a length of 76 , a height of 68 , and a diameter of $22 \mathrm{~mm}$.

The species has not, so far, been identified from any locality south of Acapulco, though a species of which I have seen no specimens and which may be the same has been reported from Panama and the Galapagos Islands.

Once segregated, this species is unmistakable, but the orbicularis, being a very common and supposedly widely distributed shell, is often mixed with it in lots supposed to be wholly West American. West Indian shelis are often imported in quantity to West Mexican ports for sale to tourists, and, unless authentically collected by a reliable person, the localities for shells obtained from dealers are always subject to a little doubt.

CODAKIA CUBANA, new species.

\section{(Plate XLII, fig. 4.)}

Shell small, thin, subcompressed, whitish, with an obvious pale olivaceous periostracum; surface with a small anterior and larger posterior dorsal area, distinguished by an absence of radial sculpture and the somewhat more prominent concentric lines of growth; the rest of the disk with feeble, nearly uniform radial threads, separated by shallow 
radial sulci; beaks nearly central, small, recurved; lunule small, narrow, impressed, confined to one valve, usually the right; escutcheon absent, ligament normal but feeble; teeth normal but small and delicate, the laterals tending to obsolescence; adductor and pallial scars normal, the interpallial space with a strong oblique sulcus; interior of the disk more or less radially striate; margins crenulate below. Alt. 17.5 , lon. 19.0, diam. $7.5 \mathrm{~mm}$.

Dredged off the coast of Cuba in the Gulf of Mexico, in 84 fathoms.

CODAKIA (JAGONIA)-PORTORICANA, new species.

(Plate XXXIX, fig. 6.)

Shell small, plump, oblique, inequilateral, white or yellowish; anterior end larger, produced downward and forward; posterior end shorter and smaller; surface sculptured with numerous radial sulci, separated by wider flattish interspaces crossed by rather regular, moderately separated, concentric elevated threads, the radials obsolete on the inconspicuous dorsal areas; lunule elongated, moderately impressed, escutcheon short, narrow, inconspicuous; beaks high, rather small, apically smooth and polished, prosogyrate; hinge normal, delicate, the laterals in the right valve well developed; ligament feeble, short; interior more or less striate, radially; basal margin finely crenulate. Alt. 6.7 , lon. 7.5 , diam. $6.0 \mathrm{~mm}$.

The figured specimen, the largest valve obtained, is from San Juan Harbor; smaller ones were dredged in the harbor of Mayaguez.

This inconspicuous little species appears to be rare, and comes nearest to Jagonia costata d'Orbigny, than which it is more finely and evenly sculptured, beside being a more tumid and smaller shell. In preparing the Porto Rico report this species was overlooked.

CODAKIA (JAGONIA) MEXICANA, new name.

(Plate XL, fig. 6.)

One of Reeve's figures in the Iconica (fig. 33) appears to represent this species, which is very similar to the West Indian $C$. orbiculata Montagu. I find, however, on careful examination that in the west coast shell the lunule is narrower, longer, and less deeply impressed than in $C$. orbiculata, the shell is more delicate, thinner, and more flattened toward the lower margins, the sculpture is more regular and the concentric threads less crowded, so that while the difference is not great the effect in $C$. mexicana is much more elegant; toward the ends it has the radials stouter and with wider interspaces, and with the sculpture on the dorsal areas less distinct from that on the disk than it is in the West Indian form. It is most commonly labeled Lucina bella Conrad, in collections, and by Carpenter was named L. pectinata, though it is not the pectinata of Gmelin or C. B. Adams. A fullgrown specimen measures: alt. 21 , lon. 23 , diam. $10.0 \mathrm{~mm}$. 
CODAKIA (JAGONIA) GALAPAGANA, new species.

(Plate XL, fig. 4.)

Shell of moderate size, moderately convex, white or with a yellowish flush, most conspicuous in the interior and frequently with a ferruginous tinge about the posterior dorsal area. It much resembles $C$. orbiculata Montagu, of the West Indies, but its most conspicuous feature is its somewhat loose and irregular radial sculpture in which the ribs are bifurcate or trifurcate distally, somewhat as in $C$. costata d'Orbigny. The lunule is nearly evenly divided between the valves, the dorsal areas inconspicuous, and the radials on the posterior area have a tendency to become minutely nodulous. The figured specimen is from Indefatigable Island, and measures: alt. 19, lon. 19.5; diam. $9.0 \mathrm{~mm}$. Another has the alt. 21 , lon. 23 and diam. $9 \mathrm{~mm}$. It appears to be common on the shores of the Galapagos Islands, but has not been found on the American coast or elsewhere as far as known.

CODAKIA (JAGONIA) CHIQUITA, new species.

\section{(Plate XXXIX, fig. 1.)}

Shell small, suborbicular, flattish, of a yellowish white color, with the beaks small, rather elevated and erect but not tumid; sculpture of regular, sublamellose, concentric, rather crowded threads, under which are numerous fine, often nearly obsolete, radial threads frequently bifurcate distally, less prominent on the middle of the disk and absent from the dorsal areas; lunule well impressed, subequally divided between the valves, short and sublanceolate; hinge and ligament delicate, normal, with no visible escutcheon, lateral teeth feeble; interior polished, the margins minutely crenulate. Alt. 9.7, lon. 10.0, diam. $4.5 \mathrm{~mm}$.

This has only been found at one locality on the west side of the lower end of the peninsula of Lower California, nearly abreast of La $\mathrm{Paz}$, in 66 fathoms.

\section{LUCINA PHENAX Dall and Simpson.}

\section{(Plate XL, fig. 3.)}

This pretty little species was discovered too late to be figured in the Porto Rico report, and I have therefore inserted the illustration of it here. It is of a white color and delicate texture, quite tumid, and so much resembles a Loripinus that it would be immediately taken for one, tut a careful inspection of the hinge shows that the ligament is external and the hinge that of a typical Lucina. The specimen figured is from San Juan Harbor in 5 fathoms and measures: Alt. 8.8. lon. 10, diam. $3.5 \mathrm{~mm}$. 


\section{LORIPES CLAUSUS Philippi.}

I have some doubt as to the original habitat of this species, as a vessel having West African ballast seems to have been wrecked at Belize, and the Rev. W. A. Stanton collected several dead shells which appear to have come from this ballast, and it is possible this should be included among them. It was originally described with no habitat.

PHACOIDES (LUCINOMA) FILOSUS Stimpson.

(Plate XL, fig. 11.)

The general confusion which has reigned for some time in regard to the Lucinoids of the group typified by this species, and of which Lucina boreatis Linnæus is a peripheral form, has led to a number of misidentifications by the writer, as well as by Cooper, Carpenter, and others, in the past. The Pacific coast form is so near to filosus that when it was not identified with $L$. borealis or the Miocene multilineatus the name given by Stimpson to the New England form was almost always applied to it. Though there is quite a range of variation in these species, they can invariably be separated by the characters of the deep, narrow sulcus in which the ligament lies. In $P$. filosus the sides of this sulcus rise perpendicularly on each side of the ligament, forming a high keel, and the sides of the lunule show this in a less, but still a noticeable, degree. In $P$. anmulatus, on the other hand, the top of the ligament is as high or higher than the sides of the sulcus in which it lies, and the lunule is similarly shallow. The posterior dorsal margin in filosus is generally more arcuate, but this is not an invariable character. In order to illustrate the comparison, figures are given of the interior of a valve of each. In the figure given in Proc. U. S. Nat. Mus., XIII, 1890, pl. XVII, fig. 5, by an error of the draughtsman the anterior adductor scar is incorrectly represented as short. The correct proportion is shown in our present figure.

\section{PHACOIDES (LUCINOMA) ANNULATUS Reeve,}

(Plate XL, fig. 10.)

See remarks under the preceding species. The present figure is from a specimen collected at Clayoquot, Vancouver Island, measuring alt. 50 , lon. 58 , and diameter $19 \mathrm{~mm}$. It is a curious fact that the Miocene $P$. contractus Say more closely resembles the Pacific coast recent shell than it does the living species of the adjacent Atlantic coast.

\section{PHACOIDES (CALLUCINA) RADIANS Conrad.}

(Plate XLII, fig. 8.)

Conrad's figure of this species ${ }^{1}$ is very poor, and the identification depends upon his specimens rather than his illustration. The same 
specific name had been chosen by Deshayes for a species of Diplodonta, but as these belong in different families and were long since separated, it does not seem as if the specific name need be changed, as was done by d'Orbigny, who called the French fossil subradians.

A better figure than Conrad's was given by Tuomey and Holmes, but this being accessible to few students, I have refigured the species from a recent specimen, $20 \mathrm{~mm}$. in height, collected at Pensacola, Florida.

\section{PHACOIDES (CALLUCINA) BERMUDENSIS, new species.}

(Plate XXXIX, fig. 5.)

Reeve's figure of lenticula in the Iconica fairly well represents this species, though I can not be certain that the shells are identical, since Reeve gives no data in regard to the hinge or interior. His name at any rate is preoccupied, and it is probably best to treat our specimens as new.

Shell small, discoid, suborbicular, white or brownish, equilateral; beaks small and low but acute; lunule long and narrow, moderately impressed; escutcheon and dorsal areas absent or obsolete; sculpture of close, fine, sharp, concentric lamellæ with slightly wider concentrically striated interspaces; there is no radial sculpture; hinge strong, muscular impressions normal, groove for the ligament long, shallow; margins of the shel! without crenulation. Alt. 16.5, lon. 17.0, diam. $7.0 \mathrm{~mm}$.

This species somewhat resembles $P$. radians, but is entirely destitute of any radial sculpture, and has a proportionately longer and narrower lunule, less deeply impressed.

\section{PHACOIDES (PARVILUCINA) CRENELLA, new species.}

(Plate XXXIX, fig 2.)

The small shells of this type from the Oligocene to the living fauna have been called by the name of "Lucina crenulata Conrad," without exception, and their differences ascribed to "variability." Careful study shows in this, as in other cases, that several distinct species should be recognized. The original locality of Conrad's shell is the Miocene of Suffolk, Virginia, where it is found abundantly. With this as a standard the others have been compared. The living shell hitherto confounded with it is represented in the fossil state in the Pleistocene of North Creek, Florida, and Simmons Bluff, South Carolina, the Pliocene of North and South Carolina, and of the Caloosahatchie beds, Florida. It does not appear in the Miocene. In the present fauna it has a wide range. It differs from the true crenulatus as follows: It is thinner, more delicate, with a less heavy hinge, more tumid valves, and is generally more equilateral and the beaks more central. $P$. crenulatus has prominent, almost, lamellose concentric sculpture, 
which is frankly lamellar on the ridges of the posterior dorsal area, which are separated by a more marked radial sulcus and have the whole area relatively wider than in $P$. crenella; in the interspaces only is the radial sculpture of $P$. crenulatus visible and it is composed of close-set threads usually uniform and rather strong; $P$. crenella has the concentric sculpture of low, very fine threads or sulci which do not conceal any part of the radial sculpture, which is feebler, less compact, and more inconstant than in the Miocene shell, being frequently almost entirely obsolete. The lunule in the two species is similar, being larger and less impressed in the left than in the right valve. The crenulation of the inner margin of the valves is stronger, closer, and more prominent in the Miocene shell, in harmony with the stronger radial sculpture.

The specimen figured is from Palma Sola, Florida, and measures $6.5 \mathrm{~mm}$. in height, 6.7 in length, and 4.5 in diameter. The Lucina crenulata of Searles Wood in the Crag monograph is a species belonging to the same group, but apparently distinct from either of the Ameri. can forms.

\section{PHACOIDES (PLEUROLUCINA) UNDATUS Carpenter.}

(Plate XXXIX, fig. 14.)

A figure of this elegant and hitherto unfigured species is now furnished. The specimen shown is from the Gulf of California, and measures $10 \mathrm{~mm}$. in height. A larger size is common, but our freshest and best specimens are mostly only adolescent.

PHACOIDES (BELLUCínA) AMIANTUS, new species.

(Plate XXXIX, fig. 10.)

This is another case in which allied species have been indiscriminately lumped. Fortunately the name costata, which has been generally used for it, is unavailable, leaving us free to name the component species without regard to the original type of Tuomey and Holmes, which is different from that of Holmes in his Pleistocene volume, both being very inadequately figured. Similar species occur from the Oligocene to recent seas and on both east and west coasts of America.

Shell small, solid, white, usually subequilateral with strong sculpture and hinge; beaks variable, usually rather conspicuous; sculpture of about twelve strong, flattish, radial ribs, separated by deep, narrower, channeled interspaces, less distinct basally in senile specimens; the ribs are crossed by numerous adjacent, flat, strap-like threads, which in well-developed specimens seem to bridge the interspaces; dorsal areas large and conspicuous; anterior with two broad wave-like radials, sometimes slightly lamellose; posterior with one slender radial, which, with the boundary rib in front of the area, is conspicuously nodular; lunule small, deeply impressed, ill defined; hinge and muscular impres- 
sions normal, strong; inner mrgins finely crenulate. Alt. 7.6, lat. 8.3, diam. $6 \mathrm{~mm}$. Most specimens are one-third smaller. The varieties are chiefly in asymmetry, some specimens having the beaks very posterior, especially in the young; the radial ribs are sometimes bifurcate distally, and the concentric sculpture varies in strength and condensation. The P. cancellaris Philippi is the Pacific coast analogue.

\section{PHACOIDES (HERE) RICHTHOFENI Gabb.}

(Plate XL, figs. 7, 9.)

Views of a young specimen from 15 fathoms, gravel, on the north side of Catalina Island, California, are given. The adilts have a much more cavernous lunule. The figured specimen measures: alt. 13.0, lat. 14.5 , diam. $7.5 \mathrm{~mm}$.

PHACOIDES (CAVILUCINA) LAMPRUS, new species.

\section{(Plate XXXIX, fig. 9.)}

Shell of Dosinioid form, solid, nearly orbicular, slightly convex, suffused with yellow or pink, strongest on the interior of the shell, or plain white; beaks subcentral small, prosogyrate, with a small, more or less excavated lunule usually almost confined to the right valve; sculpture chiefly of fine, low, rather sharp, concentric threads with occasional sulci, due to resting stages, near the margin in senile specimens; radial sculpture comprising more or less microscopic striulations and a broad shallow flexuosity of the posterior dorsal area, which is often obsolete; dorsal areas inconspicuous; hinge and muscular impressions normal, basal margins very minutely crenulate. Alt. 23.5 , lat. 23.5 , diam. $10.5 \mathrm{~mm}$.

The figured specimen is from La Paz, Lower California. This species has long been known in Pacific coast collections as Lucina excavata Carpenter, a name preoccupied in the genus, but a camera lucida drawing of his type of excavata by Carpenter shows that his type specimen was a young valve of Here richthofeni, afterwards described from fossil specimens by Gabb. The amount of excavation of the lunule in $P$. lamprus varies in individuals, and between the two valves. It seems to be relatively greater in the young, contrary to the rule in richthofeni. The solidity and thickness of the shell are notable.

\section{PHACOIDES (CAVILUCINA) LINGUALIS Carpenter.}

(Plate XXXIX, fig. 7.)

This species, I believe, though abundant in the Gulf of California, has never been figured. Therefore I thought it useful to illustrate it. It is the west coast analogue of $P$. trisulcatus Conrad. Phacoides $(C$. $)$ prolongatus Carpenter appears to be distinct, from the specimens I have seen, all of which are poor. It is smaller, higher in proportion, and with more prominent beaks. 


\section{PHACOIDES (LUCINISCA) NUTTALLII var. CENTRIFUGUS Dall.}

(Plate XXXIX, fig. 13.)

P. nuttallii is one of the most attractive of the West American species. Its elegant reticulate sculpture is usually very evenly distributed. Some specimens from the Gulf of California, however, have the concentric sculpture near the beaks more elevated and the lamellæ more widely separated, while the radial sculpture remains unchanged, thus altering the appearance of the shell very materially, especially in rather young specimens. The concentric ridges at the intersections give out little flat unciform scales or spines, extremely caducous and always lost in the adult. The general aspect of this variety is so striking that I have thought it would be useful to name and illustrate it.

The figured specimen is from 26 fathoms, sandy mud, in the Gulf of California and measures $7 \mathrm{~mm}$. in length.

PHACOIDES (LUCINOMA) HEROICUS, new species.

(Plate XLI, fig. 1.)

Shell large, moderately convex, chalky white, with a strong olivaceous periostracum; beaks small, pointed, recurved, not much elevated; dorsal areas indicated by a more emphatic flexuosity than is usual in this group; sculpture of concentric, fine wrinkles and distant, concentric, sharp, elevated lamellæ, continuous over the whole shell; ligament long, strong, in a very shallow groove; lunule long, narrow, rather deeply impressed, its periostracum darker than on other parts of the shell; teeth slender, normal, a feeble anterior left lateral is visible; muscular impressions normal, margins not crenulated. Alt. 65, lon. 71 , diam. $27 \mathrm{~mm}$.

This very fine abyssal shell is nearest to the $P$. aquizonatus Stearns (Plate XLI, figs. 2, 3), which is much smaller and more quadrate.

PHACOIDES (PARVILUCINA) TENUISCULPTUS Carpenter.

(Plate XL, fig. 5.)

This unfigured species is now illustrated from a specimen from the typical locality, Puget Sound, which has an altitude of $12 \mathrm{~mm}$.

This is one of the most abundant shells in Alaskan dredgings from over a muddy bottom, usually in 10 to 20 fathoms. Its chalky shell is almost invariably more or less abraded.

PHACOIDES (PARVILUCINA) APPROXIMATUS, new species.

(Plate XXXIX, fig. 4.)

Shell small, tumid, nearly equilateral, white with a yellowish periostracum; beaks high, full, with a rather emphatically depressed lanceolate lunule; sculpture of numerous fine, rounded, usually entire riblets separated by narrow sulci on the disk, but absent from the dorsal areas; concentric sculpture of low, feeble, distant, elevated lines which 
become feebly lamellose on the dorsal areas; hinge, especially the laterals, strong, normal; muscular scars as usual; basal margin conspicuously crenulate. Alt. 6.5 , lon. 6.3 , diam. $4.0 \mathrm{~mm}$.

The specimen figured is from the Gulf of California, in 26 fathoms, sand.

In the region south and east of Lower California this species, which is the Pacific analogue of $P$. crenella Dall, is very uniform, but toward the northern extreme of its range the radial riblets on the middle of the disk tend to become obsolete, and then the concentric sculpture is more prominent. This variety does not change its size and never reaches more than one-third the size of the northern tenvisculptus, which had doubtless the same genetic origin, judging from the material I have examined. Very conservative persons might prefer to regard the two as extremes of one polymorphic species, but so far I have not found a series which would completely unite them by gentle gradations.

\section{PHACOIDES (BELLUCINA) CANCELLARIS Philipp}

(Plate XXXIX, fig. 11.)

This very elegant but hitherto unfigured little shell is now illustrated. It is the Pacific analogue of $P$. amiantus Dall of the Atlantic coast. The specimen figured is from the Pacific coast of Lower California near the southern end of the peninsula, in 26 fathoms, sand, and measures $5.3 \mathrm{~mm}$. in length. It is a shorter shell with fewer ribs than $P$. amiantus, and the nodules on the radials of the posterior dorsal area are longer and more conspicuous.

\section{DIVARICELLA PERPARVULA, new name.}

(Plate XXXIX, fig. 8.)

This species being unfigured an illustration of it was shought desirable. The specimen figured is from Acapulco and measures $/ \mathrm{mm}$. in length.

\section{CYRENOIDA FLORIDANA Dall.}

(Plate XLII, fig. 7.)

This species, hitherto unfigured, is now illustrated. The specimen shown is from a salt pond at Boca Ciega Bay, Florida, and measures 14 mm. in length. The average specimens, however, are fully one-half smaller, and are chiefly found buried in mossy vegetation in brackish marshes.

\section{PHACOIDES (PSEUDOMILTHA?) MEGAMERIS Dall}

(Plate XLII, fig. 1.)

Lucina (Pseudomiltha?) megameris Dail, Nautilus, XV, 1901.

As this paper is composed of materials toward a monograph of American Lucinacea, it was thought that its interest might be added to by including a figure of the largest Lucinoid known, a hitherto unfigured species, represented by internal casts in the Oligocene of Clairemont, St. Anns, Jamaica, West Indies. 
This remarkable fossil, represented by a number of specimens in the U. S. National Museum (Reg. No. 147592), weighs, without any extraneous matter, 7 pounds, and the measurements are: height, 230 mm.; length $235 \mathrm{~mm}$; d diameter, $67 \mathrm{~mm}$.

The largest species hitherto recorded is the Lucina (Pseudomiltha) gigantea Deshayes, from the Parisian Eocene, and that hardly exceeds $80 \mathrm{~mm}$. in its maximum height.

If we except the Tridacnacea and a few Mytilacea, Phacoides megameris is one of the largest pelecypods known.

Supplementary note.-Some curious abyssal Pelecypods from the south Atlantic and the Philippines were described by E. A. Smith, in the Challenger Report, under the names of Cryptodon moseleyi and $C$. Tusonicus. The valves are almost perfectly plain and the hinge edentulous. According to Pelseneer, the anatomy presents the following features: There is a single anal orifice, without valvular or siphonal prolongation; the foot is hatchet-shaped, compressed, and short, with a conspicuous byssal sulcus; the form and arrangement of the adductors recalls Lepton rather than Lucina or Thyasira; the gills have on each side a single direct and reflected lamina, as in Lucina; the hepatic and visceral glands are contained within the mass of the body; the anal and peripedal chambers are separated by the union of the gills posteriorly; the anterior edges of the mantle are thickened and specialized for some - not evident-function; the palps are much as in Diplodonta.

These two species are obviously not referable to Thyasira, and the simplicity of the shell, which recalls Aximulus, gives no clue even to the family to which they should be referred. On the anatomical evidence, I propose for them the generic name of Vaticinaria.

From Thyasira and its near allies, Vaticinaria differs by its lucinoid gills and the absence of hepatic digitations, as well as by the specialization of the anterior mantle margin.

From the Diplodontida (otherwise Ungulinida) it differs by its lucinoid gills, single siphonal orifice, flattened foot, and edentulous hinge. There is no evidence of any relations with the Corbida or Cyrenellida. By this elimination we are obliged to refer the genus to the Lucinida, of which it is perhaps a degenerate member. It may have lost (as many forms have) much of its character by long residence in the abyssal region. It is least unlike such a group as Jagonia, and at any rate can not be referred with propriety to either the Thyasirida or Diplodontida. 
REFERENCES TO GENERA AND THEIR SUBDIVISIONS.

\begin{tabular}{|c|c|c|c|}
\hline Antilla & $\begin{array}{r}\text { Page. } \\
797\end{array}$ & Lentillaria ... & $\begin{array}{r}\text { Page. } \\
797\end{array}$ \\
\hline Antillia ......... . & 797 & Leptaxinus ........ & \\
\hline Anodontia .................... & 801 & Ligula .......... & \\
\hline Axina $\ldots \ldots \ldots \ldots \ldots$ & 784 & Linga ............... & \\
\hline Axinodon $\ldots \ldots \ldots \ldots$ & 784 & Lintellaria $\ldots \ldots \ldots \ldots \ldots$. & \\
\hline xinopsis . . . . . . . . & 785 & & \\
\hline & 784 & inus & \\
\hline & 784 & & \\
\hline .... & 806 & & \\
\hline (1, & 784 & a.................. & \\
\hline a $\ldots \ldots \ldots \ldots \ldots$ & 814 & ea $\ldots \ldots \ldots \ldots \ldots$ & \\
\hline & 806 & & \\
\hline & & & \\
\hline & 78 & & \\
\hline 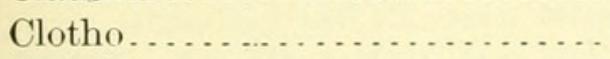 & 797 & & \\
\hline ….......... & 797 & …......... & \\
\hline (n....... & & & \\
\hline & & & \\
\hline & & & \\
\hline & 784 & & \\
\hline & 797 & & \\
\hline & & & \\
\hline & & $\mathrm{s} \ldots \ldots \ldots \mathrm{s}$ & \\
\hline & 804 & a $\ldots \ldots \ldots \ldots . . .6$. & \\
\hline & 8 & & \\
\hline & & & \\
\hline , & & , & \\
\hline … & & 19 & \\
\hline$\ldots \ldots \ldots \ldots \ldots \ldots$ & 81 & ina . . . . . . . . . . . & \\
\hline (................. & 79 & & \\
\hline & 81 & 1the & \\
\hline & 80 & & \\
\hline & & & \\
\hline & 792 & 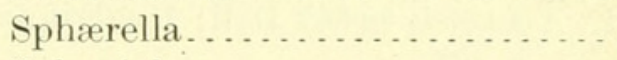 & \\
\hline & 792 & $\therefore \quad r a r$ & \\
\hline & 816 & & \\
\hline & 816 & & \\
\hline & 80 & & \\
\hline & 816 & (n) & \\
\hline (n) & 798 & nta........... & \\
\hline Joannisiella . . . . . . . . . . . . & 792 & & \\
\hline Lenticularia $\ldots \ldots \ldots \ldots \ldots \ldots$ & 797 & Vaticinaria $\ldots \ldots \ldots \ldots \ldots \ldots$ & \\
\hline
\end{tabular}




\section{EXLANATION OF THE PLATES.}

Plate XXXIX.

FIG. 1. Codakia (Jagonia) chiquita Dall; Lower California; U. S. Nat. Mus. No. 96563; lon. 10.2 mm.; p. 823.

2. I hacoides (Parvilucina) erenella Dall; Florida; U. S. Nat. Mus. No. 60948; alt. $6.5 \mathrm{~mm}$; p p. 825.

3. Thyasira tomeana Dall; Chile; U. S. Nat. Mus. No. 108907; alt. 14.7 mm.; p. 818 ,

4. Phacoides (Parvilucina) approximatus Dall; Gulf of California; U. S. Nat. Mus. No. 96418 ; alt. 6.5 mm.; p. 828.

5. Phacoides (Callucina) bermudensis Dall; Bermuda; U.S. Nat. Mus. No. 41339; lon. $15.5 \mathrm{~mm}$.; p. 825 .

6. Codakia (Jagonia?) portoricana Dall; Porto Rico; U. S. Nat. Mus. No. 108959; lon. 7.25 mm.; p. 822 .

7. Phacoides (Cavilucina) lingualis Carpenter; Gulf of California; U. S. Nat. Mus. No. 73687 ; alt. 12.5 mm.; p. 827.

8. Divaricella perparvula Dall; Acapulco, Mexico; U. S. Nat. Mus. No. 120699; lat. $7.0 \mathrm{~mm}$.; p. 829.

9. Phacoides (Cavilucina) lamprus Dall; Gulf of California; U.S. Nat. Mus. No. 41626; lon. $17.5 \mathrm{~mm}$; p. 827.

10. Phacoides (Bellucina) amiantus Dall; Yucatan Strait; U. S. Nat. Mus. No. 64276 ; alt. $7.6 \mathrm{~mm}$.; p. 826.

11. Phacoides (Bellucina) cancellaris Philippi; Lower California; U. S. Nat. Mus. No. 96440 ; lon. 5.3 mm.; p. 829.

12. Thyasira excavata Dall; Gulf of California; U. S. Nat. Mus. No. 107449; alt. $21 \mathrm{~mm}$. ; p. 818.

13. Phacoides (Lucinisca) nuttallii Conrad, var. centrifugus Dall, young; Gulf of California; U. S. Nat. Mus. No. 108881; lon. 7.0 mm.; p. 828.

14. Phacoides (Pleurolucina) undatus Carpenter; Gulf of California; U. S. Nat. Mus. No. 73685 ; alt. $10 \mathrm{~mm}$.; p. 826.

15. Thyasira excavata Dall; interior of valve represented by fig. 12, supra.

\section{Plate XL.}

Fig. 1. Axinopsis viridis Dall; Unalaska; U. S. Nat. Mus. No. 108925; lon. $6.2 \mathrm{~mm}$. p. 819.

2. 1xinopsis sericatus Carpenter; type specimen for comparison with fig. 1; Puget Sound; U. S. Nat. Mus. No. 5249; lon. 4.0 mm.; p. 819.

3. Lucina phenax Dall and Simpson; Porto Rico; U. S. Nat. Mus. No. 103951; alt. $9.0 \mathrm{~mm}$.; p. 823 .

4. Codakia (Jagonia) galapagana Dall; Galapagos Islands; U. S. Nat. Mus. No. 102454; lon. 23 mm.; p. 823.

5. Phacoides (Parvilucina) tenuisculptus Carpenter; Puget Sound; U. S. Nat. Mus. No. 108827; alt. 12 mm.; p. 828.

6. Codakia (Jagonia) mexicana Dall; Gulf of California; U. S. Nat. Mus. No. 101783; lon. 23 mm.; p. 822.

7. Phacoides (Here) richthofeni Gabb; young shell from Catalina Island, California; U. S. Nat. Mus. No. 108828; lon. 14.5 mm.; p. 827.

8. Thyasira bisecta Conrad (sp.), viewed from above; southeastern Alaska; U.S. Nat. Mus. No. 122556; lon. 50 mm.; p. 817.

9. Phacoides (Here) richthofeni Gabb, interior of the valve represented by fig. 7, showing excavation of lunule and muscular impressions. 
Fig. 10. Phacoides (Lucinoma) ammulatus Reeve, Vancouver Island; interior of shell; U. S. Nat. Mus. No. 150971; lon. 58 mm.; p. 824.

11. Phacoides (Lucinoma) filosus Stimpson; off Newport, Rhode Island; figured for comparison with the preceding; lon. $49 \mathrm{~mm}$; p. 824.

\section{Plite XLI.}

Fig. 1. Phacoides (Lucinoma) heroicus Dall; western Mexico; U. S. Nat. Mus. No. 108818; lon. $71 \mathrm{~mm}$; p. 828.

2-3. Phacoides (Lucinoma) xquizonatus Stearns; Santa Barbara Channel, California; interior and exterior of shell; U. S. Nat. Mus. No. 104044; lon. 45 mm.; p. 813.

4. Codakia colpoica Dall; Gulf of California; U. S. Nat. Mus. No. 102435; lon. $76 \mathrm{~mm}$; p. 821 .

\section{Plate XLII.}

Fig. 1. Phacoides (Pseudomiltha?) megameris Dall, an internal cast from Clairemont, St. Ann's, Jamaica, West Indies, Oligocene Tertiary limestone; U. S. Nat. Mus. No. 147592; max. length $235.0 \mathrm{~mm}$; p. 829.

2. Thyasira conia Dall and Simpson, Porto Rico; U. S. Nat. Mus. No. 108949; alt. $5.5 \mathrm{~mm}$; p. 818 .

3. Diplodonta (torelli Jeffreys, var.?) aleutica Dall, young shell; Kyska Island, Aleutians; U. S. Nat. Mus. No. 108845; lon. $15.3 \mathrm{~mm}$; p. 820.

4. Codakia cubana Dall, off Cuban coast in the Gulf of Mexico; U. S. Nat. Mus. No. 64279 ; lon. $18.5 \mathrm{~mm}$; p. 821.

5. Thyasira bisecta Conrad (sp.), Alaska; U. S. Nat. Mus. No. 122556; lon. 50 mm.; p. 817 .

6. Thyasira magellanica Dall, western Patagonia; U. S. Nat. Mus. No. 122745; alt. $4.7 \mathrm{~mm}$; p. 819 .

7. Cyrenoida floridana Dall, Florida; U. S. Nat. Mus. No. 60973; lon. 14.0 mm.; p. 829.

8. Phacoides (Callucina) radians Conrad, Pensacola, Florida; U. S. Nat. Mus. No. 126914 ; alt. $20.0 \mathrm{~mm}$.; p. 824.

Proc. N. M. vol. xxiii- 53 


\section{$2 \mathrm{BHL}$ Biodiversity Heritage Library}

Dall, William Healey. 1901. "Synopsis of the Lucinacea and of the American species." Proceedings of the United States National Museum 23(1237), 779-833. https://doi.org/10.5479/si.00963801.23-1237.779.

View This Item Online: https://www.biodiversitylibrary.org/item/32360

DOI: https://doi.org/10.5479/si.00963801.23-1237.779

Permalink: https://www.biodiversitylibrary.org/partpdf/26656

\section{Holding Institution}

Smithsonian Libraries

\section{Sponsored by}

Smithsonian

\section{Copyright \& Reuse}

Copyright Status: NOT_IN_COPYRIGHT

This document was created from content at the Biodiversity Heritage Library, the world's largest open access digital library for biodiversity literature and archives. Visit BHL at https://www.biodiversitylibrary.org. 